\title{
Design of reinforced concrete walls casted in place for the maximum normal stress of compression
}

\section{Dimensionamento de paredes de concreto armado moldadas no local para a máxima tensão normal de compressão}
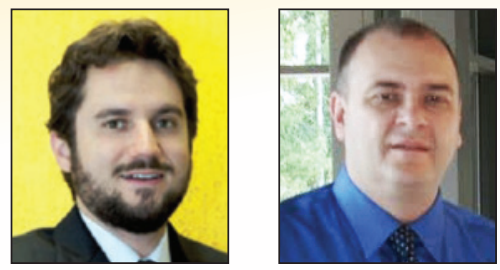

T. C. BRAGUIM a thales@osmb.com.br

T. N. BITTENCOURT a tbitten@gmail.com

\section{Abstract}

It is important to evaluate which designing models are safe and appropriate to structural analysis of buildings constructed in Concrete Wall system In this work it is evaluated, through comparison of maximum normal stress of compression, a simple numerical model, which represents the walls with frame elements, with another much more robust and refined, which represents the walls with shells elements. The designing of the normal stress of compression it is done for both cases, based on NBR 16055, to conclude if the wall thickness initially adopted, it is enough or not.

Keywords: reinforced concrete walls; numerical models; normal stress of compression.

\section{Resumo}

É fundamental se conhecer quais modelos numéricos são seguros e pertinentes para a análise estrutural de edificações construídas pelo sistema Paredes de Concreto. Neste trabalho é avaliado, por meio da comparação da máxima tensão normal de compressão, um modelo numérico mais simples, que discretiza as paredes em elementos de barra, com outro mais robusto e refinado que discretiza as paredes com elementos de casca. A verificação do dimensionamento da máxima tensão normal de compressão é realizada para os dois casos, considerando as premissas da norma brasileira NBR 16055 a fim de concluir se a espessura das paredes adotada inicialmente é suficiente ou não.

Palavras-chave: paredes de concreto armado; modelos numéricos; tensão normal de compressão. 


\section{Introduction}

Since 2007, a significant use of the system known as Concrete Wal has been influenced the Brazilian residential construction market. In April 2012, a Brazilian code exclusively devoted to this system was published. Besides that, the challenge in reducing housing deficit stimulate the use of this alternative method, because when properly applied it provides high productivity and lower costs compared with other construction methods. As it is a constructive method which the main concept brings the idea of the industrialization of the construction, it is important to highlight that it is necessary to considerer the time for the structure execution (one vantage of the Concrete Wall System because it is considered fast), to make a realistic comparison of costs between it and the conventional method or the structure masonry, for instance. In terms of structural design it is important to evaluate which designing models are safe and appropriate to structural analysis of buildings constructed in Concrete Wall System. This work presents the comparison of results between some possible numerical models to design a concrete wall for the maximum normal stress of compression, as the recent Brazilian code NBR 16055:2012 - Concrete wall castes in place for building construction - Requirements and proceedings [4].

\subsection{Initial consideration}

In the structural design of buildings constructed by Concrete Walls system, the thickness of the walls is one of the main settings to be made. This definition involves several variables such as, the height of the building, the external forces acting in it, the resistance of the materials used and the assumptions of how these walls are represented numerically.

Normally the walls of a building of concrete walls are subjected to normal compressive stresses that are superior on the normal tensile and shear stresses. Thus, the definition of wall thickness is made by comparing the maximum normal stress of compression with the ultimate normal stress of compression according with some code.

\subsection{Aims}

This study aims to compare the maximum normal stress of compression in the critical cross section of the concrete walls of a building, obtained by two different numerical models, and verify it with the ultimate strength of compression calculated by the NBR 16055 [4]. From the comparison of results is a purpose evaluate the quality of the simpler model over more refined model and see if the wall thickness adopted initially is sufficient.

\subsection{Method}

It was used as a study case, the building Condomínio das Árvores, built in 2012 in São Bernado do Campo by construction Sergus Construções e Comércio Ltda.

The building was modeled using the finite element method. The first model, called Finite Element Model (MEF), and taken as a reference model for the comparison of results to be the most refined, represents the walls with shell Tridimensional Frame Model (MPT). First, the distribution of vertical loads on the walls is done according to each numerical model. The concentrated characteristic normal force, obtained only by vertical loads, is compared between the models at the foundation level, in order to verify the differences.

Then the characteristic normal forces and bending moments obtained from some walls, considering only horizontal actions, are compared through their diagrams.

The combination of vertical and horizontal actions is done to obtain the maximum normal stress of compression. This result is compared between the two models on some walls of the studied building.

Finally, it is calculated the ultimate strength of compression using the expression given in NBR 16055 [4], and it is checked whether the thickness of the walls of the building studied initially adopted, it is enough to resist to normal stresses of compression.

It is noteworthy that the NBR 16055 [4] covers concepts that go beyond the NBR 6118:2007 - Design of concrete structures - Procedures [1], such as the definition of concrete wall. According to NBR 16055 [4], in item 14.4, a concrete wall is defined when the length of the wall is greater than or equal to ten times its thickness. The NBR 6118 [1] defines pillar-wall, on your item 14.4.2.4, when the largest cross-sectional dimension of a pillar is greater than or equal to 5 times their smaller size. Another observation is that this paper brings a study of walls, and not wall-beams. That means that the concrete walls analyzed have continuous support throughout your base, unlike the wall-beams that have discrete support.

The numerical models (FEM and MPT) were developed in

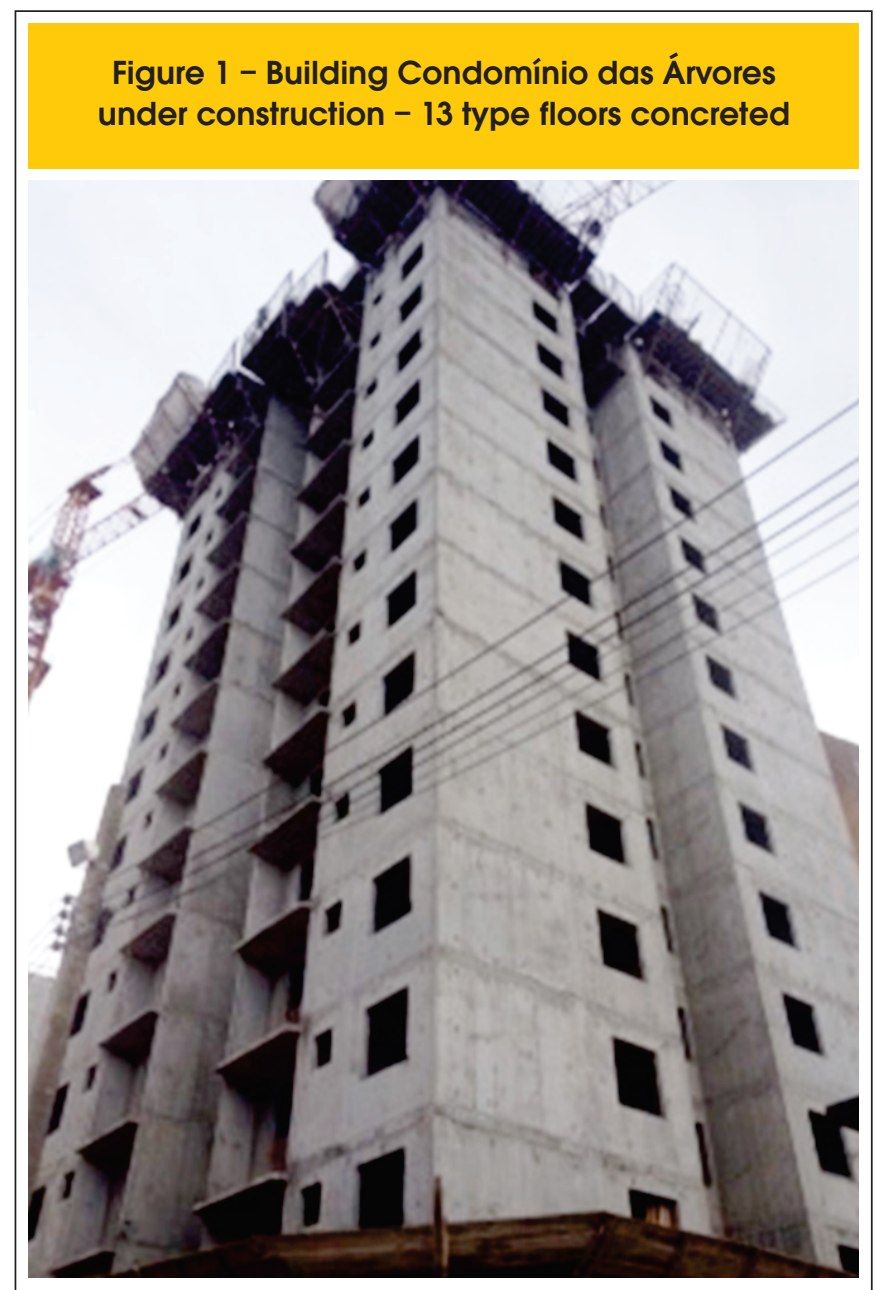


SAP2000 software - version 15, based on the Finite Element Method, considering linear elastic analysis. The interaction between soil and structure was not considered.

\section{Study case}

It was used an adaptation of the building Condomínio das Árvores of the enterprise Reserva Jardim Botânico, built in the city of São Bernardo do Campo, in 2012, by the construction Sergus Construções e Comércio Ltda, as shown in Figure [1]. The structural design was provided by OSMB Engineers and Associates S / S Ltda.

The geometry of the building was adapted in relation to the building constructed in order to simplify the numerical modeling. Howev$\mathrm{er}$, its main features have been retained. All measurements were multiple of $40 \mathrm{~cm}$, and the number of floors was adopted equal to fifteen types, thus not having the transition from the ground to the first floor and the attic, provided for in the original design. It was considered the distance between floors of $2.80 \mathrm{~m}$. The Figure [2] shows the type floorplan with walls and lintels (regions above and below doors and windows) of reinforced concrete, named as the horizontal and vertical directions. Though the massive concrete slabs are not named in Figure [2], they were considered in the whole floorplan, with a thickness of $10 \mathrm{~cm}$, except in pressurization, lift and installations openings, where a hole is represented by $X$. The stairwell was considered to be a massive slab of $10 \mathrm{~cm}$ thick. The only pillar in the structure is also made with reinforced concrete and it is located at the middle of the stairwell. In the floorplan it is represented by a hatch in red.

\section{Loads considered}

\subsection{Vertical loads}

The vertical loads considered were the permanent loads (dead loads) and the accidental loads (live loads) according to NBR 6120 [2]. For that were considered:

- own weight for the structure elements: $\gamma=250 \mathrm{kN} / \mathrm{m}^{3}$;

- permanent loads (dead loads): $g_{L}=1,0 \mathrm{kN} / \mathrm{m}^{2}$;

accidental loads (live loads): $q_{L}=1,5 \mathrm{kN} / \mathrm{m}^{2}$.

To calculate the reactions of slabs on the walls, it was used the method of plastic hinges which is based in the approximate position of the break lines that define the areas of influence of the slabs on the walls.

Figure [3] shows the areas of influence of the slabs to unload their loads in walls and lintels by the method of plastic hinges.

The values of the areas of influence $\left(A_{L}\right)$, lengths of influence $\left(L_{\text {inf }}\right)$, along which the load of their area of influence is distributed in the walls and/or lintels and the concentrated loads $(P)$ and distribut-

Figure 2 - Type floor plan of the study case: geometry $(\mathrm{cm})$ and names of walls and lintels

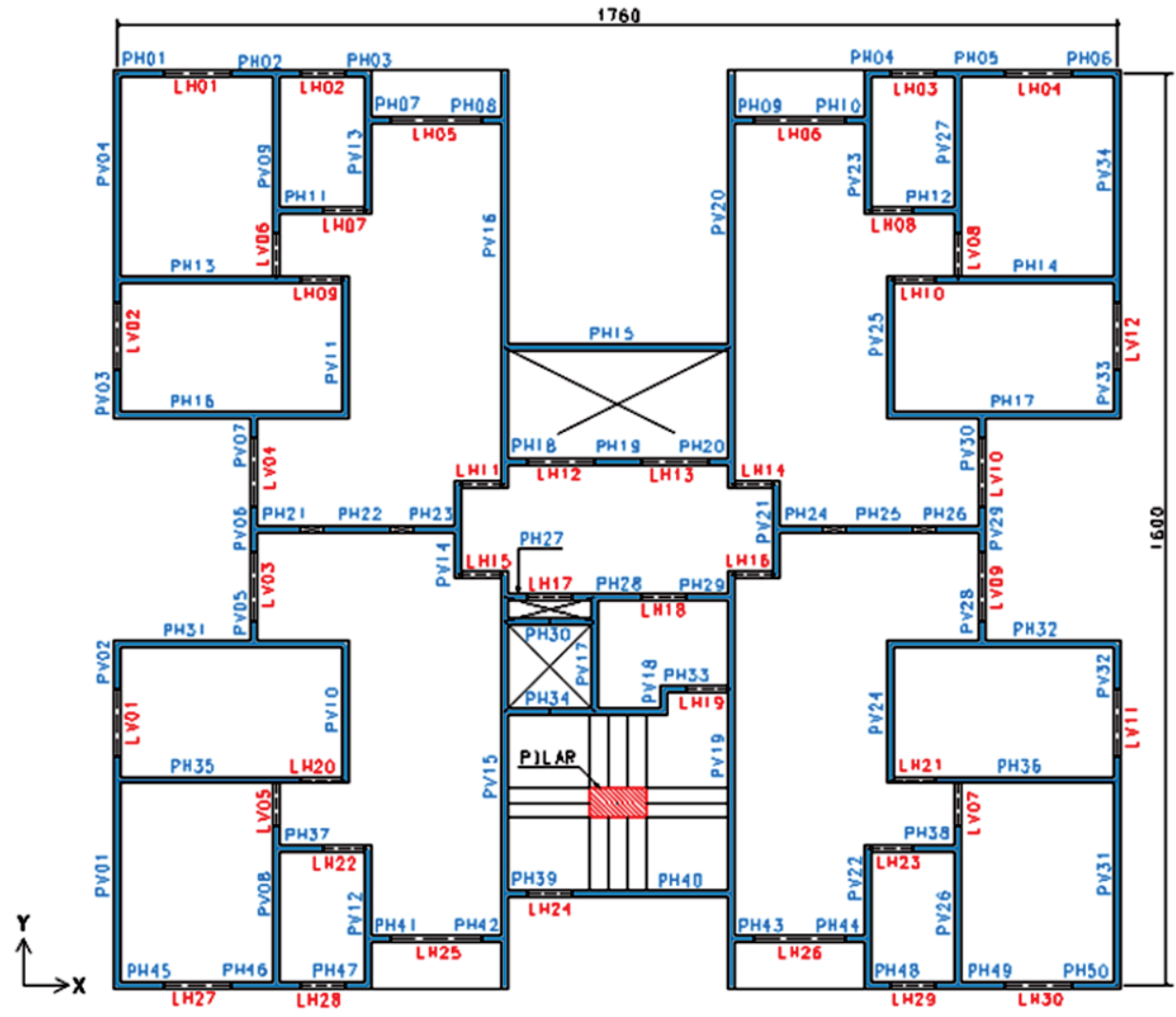


Figure 3 - Areas of influence of the slabs on the walls and lintels

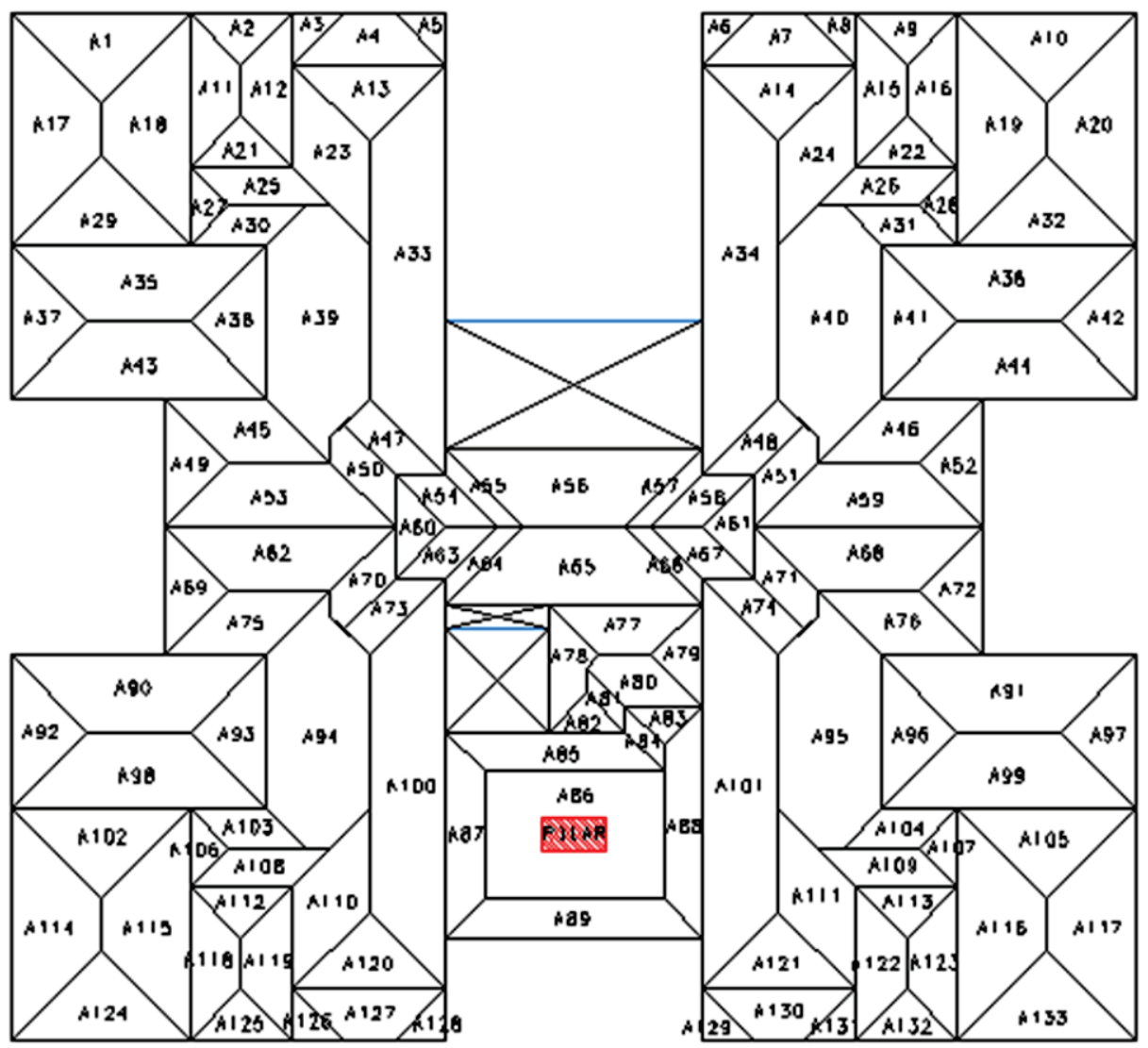

ed loads (p), acting in the length of influence, are shown in Table [1]. Corrêa and Ramalho [7] reported that the definition of how the action of the slabs on the walls that serve as support takes place, and also how interactions occur between walls, are crucial to obtain a coherent structural analysis aspects of the walls.

\subsection{Horizontal loads}

This work was just considered horizontal loads due to wind and out of plumb load, centered.

The ABNT NBR 6123:1988 - Forces due to wind on buildings [5], allows to transform the wind pressures that fall perpendicularly on the surface of the walls in static forces. For this it is necessary to define the characteristic wind speed as shown in Equation [1]:

$$
v_{k}=v_{0} \cdot S_{1} \cdot S_{2} \cdot S_{3}
$$

where $v_{k}$ is the characteristic wind velocity $(\mathrm{m} / \mathrm{s}), v_{0}$ is the basic wind speed $(\mathrm{m} / \mathrm{s}), S_{1}$ is the topographic factor, $S_{2}$ is the factor which considers the roughness of the terrain and the variation of wind speed with the height of a building and its dimensions in plan and $S_{3}$ is the statistical factor.
The dynamic wind pressure $q_{\text {vento }}\left(\mathrm{N} / \mathrm{m}^{2}\right)$ is determined by the characteristic wind velocity as pointed in item 4.2 of NBR 6123 [5], described in Equation [2]:

$$
q_{\text {vento }}=0,613 v_{k}^{2}
$$

Finally the drag force which is the component of the global wind force in a given direction is defined by Equation [3]:

$$
F_{a}=C_{a} \cdot q_{\text {vento }} \cdot A_{e}
$$

in which, $F_{a}$ is the drag force in the direction of the wind, $C_{a}$ is the drag coefficient as wind direction and $A_{e}$ is the effective frontal area on a plane perpendicular to the wind direction.

The out of plumb caused by eccentricities arising from construction of a building is considered in the structure by horizontal loads equivalents to this displacements. As indicated in the NBR 16055 [4] for multi-story buildings, must be considered a 
global out of plumb through an angle of out of plumb, calculated by Equation [4]:

$$
\theta=\frac{1}{170 . \sqrt{H}}
$$

where, $\theta$ is the angle of out of plumb (rad) and $\mathrm{H}$ is the total height of the building $(\mathrm{m})$.
The equation [5] transform the effect of the out of plumb into an equivalent horizontal force $\left(F_{1 b}\right)$ in terms of $\theta$ and total vertical load on the floor, represented by $\Delta P$

$$
F_{d p}=\Delta P \cdot \theta
$$

Table 1 - Values of the areas of influence of the slabs on the walls and lintels and their respective loads

\section{Area of influence and loads from the slabs}

\begin{tabular}{|c|c|c|c|c|c|c|c|c|c|c|c|c|c|c|}
\hline $\mathrm{Al}$ & 1,96 & 2,80 & 9,80 & 3,50 & A46 & 1,60 & 1,60 & 8,00 & 5,00 & A91 & 3,36 & 4,00 & 16,80 & 4,20 \\
\hline A2 & 0,64 & 1,60 & 3,20 & 2,00 & A47 & 0,80 & 0,80 & 4,00 & 5,00 & A92 & 1,44 & 2,40 & 7,20 & 3,00 \\
\hline A3 & 0,32 & 0,80 & 1,60 & 2,00 & A48 & 0,80 & 0,80 & 4,00 & 5,00 & A93 & 1,44 & 2,40 & 7,20 & 3,00 \\
\hline A4 & 1,28 & 2,40 & 6,40 & 2,67 & A49 & 1,00 & 2,00 & 5,00 & 2,50 & A94 & 5,12 & 2,40 & 25,60 & 10,67 \\
\hline A5 & 0,32 & 0,80 & 1,60 & 2,00 & A50 & 0,76 & 0,80 & 3,80 & 4,75 & A95 & 5,12 & 2,40 & 25,60 & 10,67 \\
\hline A6 & 0,32 & 0,80 & 1,60 & 2,00 & A51 & 0,76 & 0,80 & 3,80 & 4,75 & A96 & 1,44 & 2,40 & 7,20 & 3,00 \\
\hline A7 & 1,28 & 2,40 & 6,40 & 2,67 & A52 & 1,00 & 2,00 & 5,00 & 2,50 & A97 & 1,44 & 2,40 & 7,20 & 3,00 \\
\hline A8 & 0,32 & 0,80 & 1,60 & 2,00 & A53 & 2,60 & 3,60 & 13,00 & 3,61 & A98 & 3,36 & 4,00 & 16,80 & 4,20 \\
\hline A9 & 0,64 & 1,60 & 3,20 & 2,00 & A54 & 0,64 & 0,80 & 3,20 & 4,00 & A99 & 3,36 & 4,00 & 16,80 & 4,20 \\
\hline A 10 & 1,96 & 2,80 & 9,80 & 3,50 & A55 & 0,40 & 0,40 & 2,00 & 5,00 & A 100 & 6,24 & 6,40 & 31,20 & 4,88 \\
\hline Al1 & 1,28 & 2,40 & 6,40 & 2,67 & A56 & 3,36 & 4,00 & 16,80 & 4,20 & A101 & 6,24 & 6,40 & 31,20 & 4,88 \\
\hline $\mathrm{A} 12$ & 1,28 & 2,40 & 6,40 & 2,67 & A57 & 0,40 & 0,40 & 2,00 & 5,00 & A 102 & 1,96 & 2,80 & 9,80 & 3,50 \\
\hline $\mathrm{A} 13$ & 1,44 & 2,40 & 7,20 & 3,00 & A58 & 0,64 & 0,80 & 3,20 & 4,00 & A103 & 0,72 & 1,20 & 3,60 & 3,00 \\
\hline A 14 & 1,44 & 2,40 & 7,20 & 3,00 & A59 & 2,60 & 3,60 & 13,00 & 3,61 & Al04 & 0,72 & 1,20 & 3,60 & 3,00 \\
\hline A 15 & 1,28 & 2,40 & 6,40 & 2,67 & A60 & 0,64 & 1,60 & 3,20 & 2,00 & A 105 & 1,96 & 2,80 & 9,80 & 3,50 \\
\hline A 16 & 1,28 & 2,40 & 6,40 & 2,67 & A61 & 0,64 & 1,60 & 3,20 & 2,00 & A106 & 0,36 & 1,20 & 1,80 & 1,50 \\
\hline A 17 & 3,08 & 3,60 & 15,40 & 4,28 & A62 & 2,60 & 3,60 & 13,00 & 3,61 & A107 & 0,36 & 1,20 & 1,80 & 1,50 \\
\hline A18 & 3,08 & 3,60 & 15,40 & 4,28 & A63 & 0,64 & 0,80 & 3,20 & 4,00 & A108 & 0,96 & 1,60 & 4,80 & 3,00 \\
\hline Al9 & 3,08 & 3,60 & 15,40 & 4,28 & A64 & 0,40 & 0,40 & 2,00 & 5,00 & A109 & 0,96 & 1,60 & 4,80 & 3,00 \\
\hline A20 & 3,08 & 3,60 & 15,40 & 4,28 & A65 & 3,36 & 4,00 & 16,80 & 4,20 & A 110 & 1,92 & 1,60 & 9,60 & 6,00 \\
\hline A21 & 0,64 & 1,60 & 3,20 & 2,00 & A66 & 0,40 & 0,40 & 2,00 & 5,00 & A 111 & 1,92 & 1,60 & 9,60 & 6,00 \\
\hline A22 & 0,64 & 1,60 & 3,20 & 2,00 & A67 & 0,64 & 0,80 & 3,20 & 4,00 & A 112 & 0,64 & 1,60 & 3,20 & 2,00 \\
\hline A23 & 1,92 & 1,60 & 9,60 & 6,00 & A68 & 2,60 & 3,60 & 13,00 & 3,61 & A 113 & 0,64 & 1,60 & 3,20 & 2,00 \\
\hline A24 & 1,92 & 1,60 & 9,60 & 6,00 & A69 & 1,00 & 2,00 & 5,00 & 2,50 & A 114 & 3,08 & 3,60 & 15,40 & 4,28 \\
\hline A25 & 0,96 & 1,60 & 4,80 & 3,00 & A70 & 0,76 & 0,80 & 3,80 & 4,75 & A 115 & 3,08 & 3,60 & 15,40 & 4,28 \\
\hline A26 & 0,96 & 1,60 & 4,80 & 3,00 & A71 & 0,76 & 0,80 & 3,80 & 4,75 & A 116 & 3,08 & 3,60 & 15,40 & 4,28 \\
\hline A27 & 0,36 & 1,20 & 1,80 & 1,50 & A72 & 1,00 & 2,00 & 5,00 & 2,50 & A 117 & 3,08 & 3,60 & 15,40 & 4,28 \\
\hline A28 & 0,36 & 1,20 & 1,80 & 1,50 & A73 & 0,80 & 0,80 & 4,00 & 5,00 & A 118 & 1,28 & 2,40 & 6,40 & 2,67 \\
\hline A29 & 1,96 & 2,80 & 9,80 & 3,50 & A74 & 0,80 & 0,80 & 4,00 & 5,00 & A 119 & 1,28 & 2,40 & 6,40 & 2,67 \\
\hline A30 & 0,72 & 1,20 & 3,60 & 3,00 & A75 & 1,60 & 1,60 & 8,00 & 5,00 & $\mathrm{~A} 120$ & 1,44 & 2,40 & 7,20 & 3,00 \\
\hline A31 & 0,72 & 1,20 & 3,60 & 3,00 & A76 & 1,60 & 1,60 & 8,00 & 5,00 & A121 & 1,44 & 2,40 & 7,20 & 3,00 \\
\hline A32 & 1,96 & 2,80 & 9,80 & 3,50 & A77 & 1,28 & 2,40 & 6,40 & 2,67 & Al22 & 1,28 & 2,40 & 6,40 & 2,67 \\
\hline A33 & 6,24 & 6,40 & 31,20 & 4,88 & A78 & 0,88 & 2,00 & 4,40 & 2,20 & A 123 & 1,28 & 2,40 & 6,40 & 2,67 \\
\hline A34 & 6,24 & 6,40 & 31,20 & 4,88 & A79 & 0,64 & 1,60 & 3,20 & 2,00 & Al24 & 1,96 & 2,80 & 9,80 & 3,50 \\
\hline A35 & 3,36 & 4,00 & 16,80 & 4,20 & A80 & 0,92 & 1,20 & 4,60 & 3,83 & Al25 & 0,64 & 1,60 & 3,20 & 2,00 \\
\hline A36 & 3,36 & 4,00 & 16,80 & 4,20 & A81 & 0,24 & 0,40 & 1,20 & 3,00 & A 126 & 0,32 & 0,80 & 1,60 & 2,00 \\
\hline A37 & 1,44 & 2,40 & 7,20 & 3,00 & A82 & 0,36 & 1,20 & 1,80 & 1,50 & A 127 & 1,28 & 2,40 & 6,40 & 2,67 \\
\hline A38 & 1,44 & 2,40 & 7,20 & 3,00 & A83 & 0,36 & 1,20 & 1,80 & 1,50 & $\mathrm{~A} 128$ & 0,32 & 0,80 & 1,60 & 2,00 \\
\hline A39 & 5,12 & 2,40 & 25,60 & 10,67 & A84 & 0,24 & 0,40 & 1,20 & 3,00 & Al29 & 0,32 & 0,80 & 1,60 & 2,00 \\
\hline A40 & 5,12 & 2,40 & 25,60 & 10,67 & A85 & 1,68 & 2,80 & 8,40 & 3,00 & A 130 & 1,28 & 2,40 & 6,40 & 2,67 \\
\hline A41 & 1,44 & 2,40 & 7,20 & 3,00 & A86 & 5,60 & 1,00 & 28,00 & 28,00 & A 131 & 0,32 & 0,80 & 1,60 & 2,00 \\
\hline A42 & 1,44 & 2,40 & 7,20 & 3,00 & A87 & 1,56 & 3,20 & 7,80 & 2,44 & A 132 & 0,64 & 1,60 & 3,20 & 2,00 \\
\hline A43 & 3,36 & 4,00 & 16,80 & 4,20 & A88 & 1,80 & 3,60 & 9,00 & 2,50 & A133 & 1,96 & 2,80 & 9,80 & 3,50 \\
\hline A44 & 3,36 & 4,00 & 16,80 & 4,20 & A89 & 2,04 & 4,00 & 10,20 & 2,55 & - & - & - & - & - \\
\hline A45 & 1,60 & 1,60 & 8,00 & 5,00 & A90 & 3,36 & 4,00 & 16,80 & 4,20 & - & - & - & - & - \\
\hline
\end{tabular}

Area $A\left(m^{2}\right) L \inf (m) P(k N) p(k N / m) \quad$ Area $A\left(m^{2}\right) L \inf (m) P(k N) p(k N / m)$ Area $A\left(m^{2}\right) \quad L i n f(m) P(k N) p(k N / m)$ 


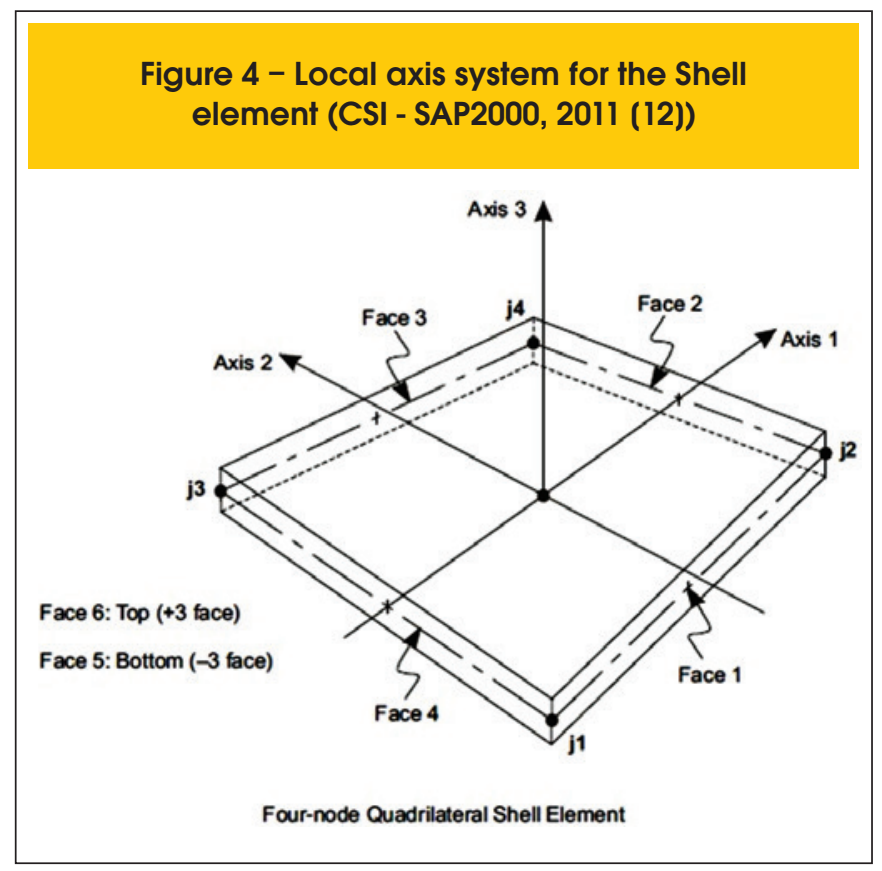

\section{Numerical models}

\subsection{Finite element model}

The Finite Element Model named in this work refers to the representation of the walls of the building analyzed in square plane shell elements, with nodes only at the vertices. It was used the shell
Figure 5 - Degrees of freedom for the node at certain finite element (CSI - SAP2000, 2011 (12))

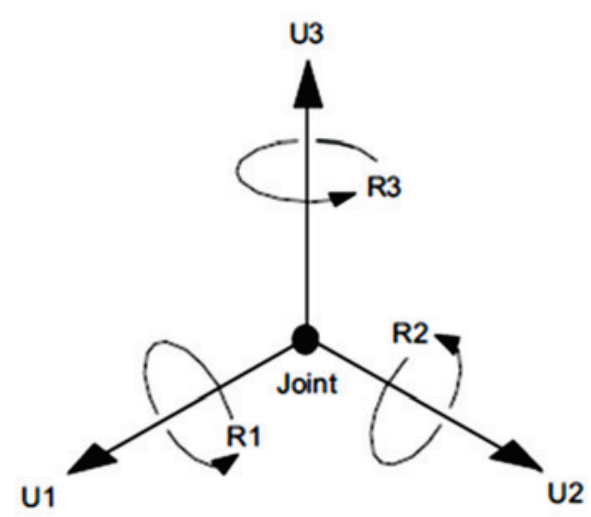

element from software SAP2000 for such modeling, with dimensions $40 \mathrm{~cm} \times 40 \mathrm{~cm}$ and thickness as the same as the wall, adopted equal to $12 \mathrm{~cm}$. The system of local axes of the element and its four nodes are shown in Fig. [4]. The degrees of freedom for the element node are shown in Figure [5]. The slabs were not represented, and to simulate its behavior, it was used the tool rigid diaphragm. Figure [6] shows the Finite Element Model of the studied building.

\subsection{Tridimensional frame model}

The Tridimensional Frame Model, named by Nascimento Neto [8],

Figure 6 - Building represented by Finite Elements Method (MEF)
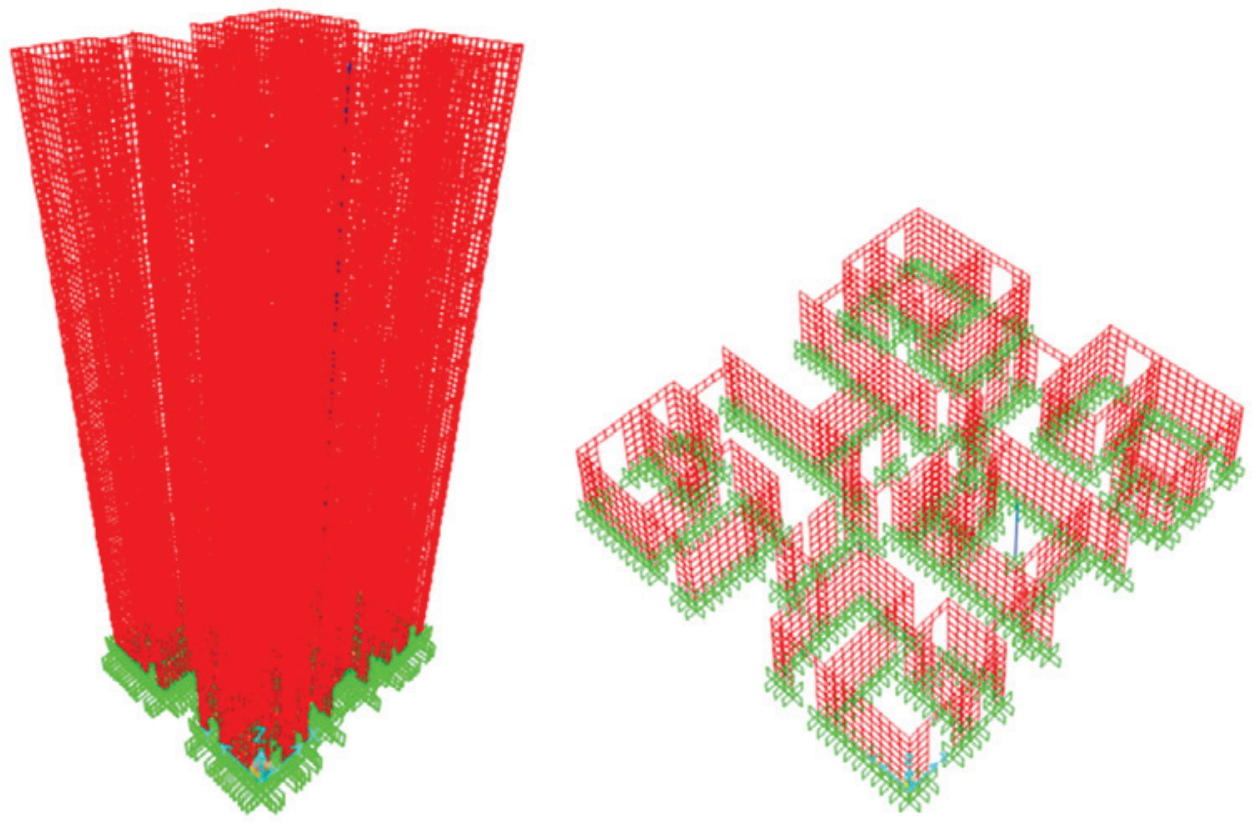
Figure 7 - Tridimensional Frame Model (CORRÊA, 2003 (6))

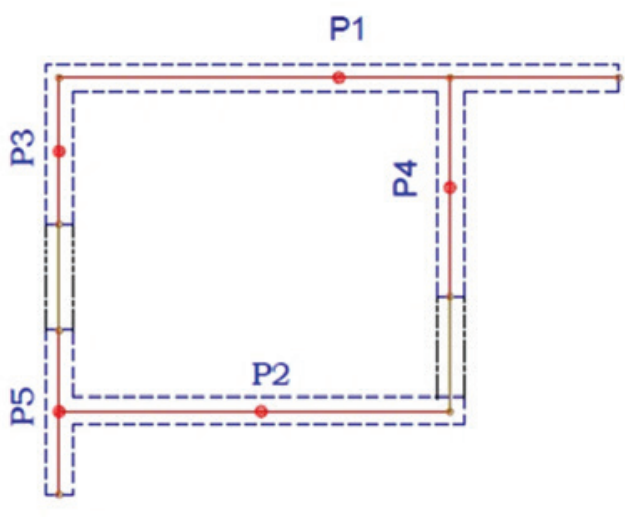

A Visão em planta

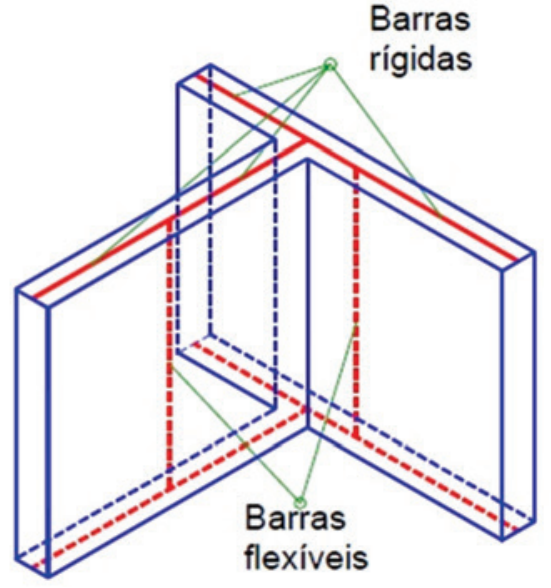

B Visão em perspectiva is an adaptation of a model proposed by Yagui [11], which makes the representation of hard-core in bar elements, horizontally restricted by slabs acting as a rigid diaphragm.

The adaptation of Yagui [11] model proposed by Nascimento Neto [8] and called Tridimensional Frame Model has small changes in the formulation of the element, making it more comprehensive. Moreover, its application has been made in structural systems composed of walls, as in the case of buildings constructed in Structural Masonry and Concrete Walls. Nunes [10] used the Tridimen- sional Frame Model to analyze the internal forces of a building of concrete walls, as well as Nascimento Neto [8] evaluated for the case of Structural masonry.

Unlike Yagui model, the Tridimensional Frame Model considers the flexural rigidity in the direction of lower inertia of the wall, because it is modeled by three-dimensional bar with six degrees of freedom at each end. However, the layout and some features of the bars in the Tridimensional Frame Model, are the same as in Yagui model, i.e.:

Figure 8 - Application of Tridimensional Frame Model

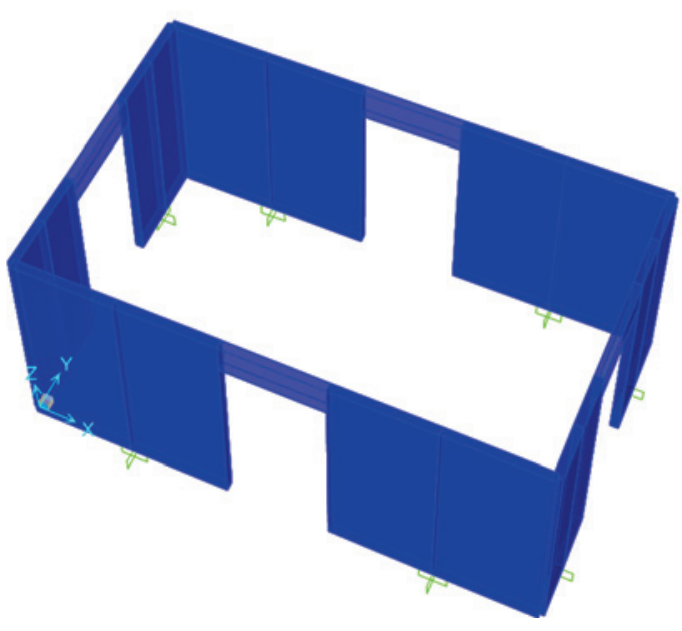

A Walls and lintels with "full" cross-section

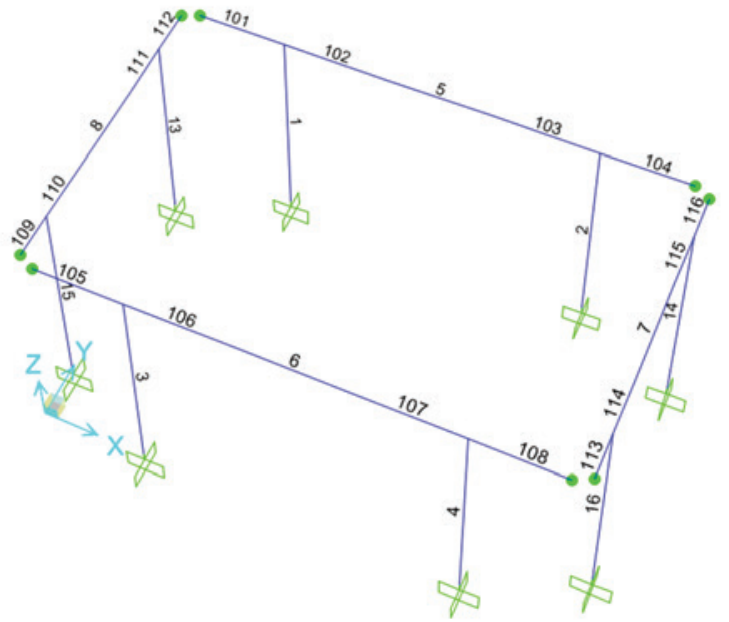

B Tridimensional vertical and horizontal bars 
a flexible vertical bar is positioned at the vertical axis of the wall having the elastic and geometric features that replaces the wall segment;

- beyond the bending deformation, the shear deformation is considered in flexible vertical bars;

- horizontal rigid bars are arranged at floor level and connect the ends of the walls to the flexible vertical bar; the height and width of the cross section is equal to the wall that the bar represents;

- the endpoints nodes of the horizontal rigid bars are articulated (except when the end is connected to a lintel or other rigid horizontal bar collinear), and the common node to the flexible vertical bar is continuous;

- horizontal rigid bars have infinite flexural rigidity in the plane and simulate the length of the walls and the interaction between them. It is important to consider the shear deformation in the vertical bar elements due to the relatively large dimensions of the walls when compared to a beam, for example. According to NBR 16055 [4], in item 14.3, for the consideration of the wall as a structural bracing system, represented by linear element component, it is necessary to consider besides the bending deformation, the shear deformation. The horizontal bars are rigid and therefore such deformation is not considered therein.

The Tridimensional Frame Model is shown in Figure [7].

As Nascimento and Corrêa [9], the walls that intersect are interlinked / connected by horizontal rigid bars, in order to consider the interaction that effectively develops between walls, which is simulated by the shear that arises in the intersection node. Thus, the horizontal rigid bars that are not collinear, has its endpoint node articulated which is as well an intersection node. So the only degree of freedom associated to this node is vertical translation.

The inclusion of lintels is also possible in this model, which greatly increases the rigidity of the building. When taken, it is necessary that the connection between the lintel and the rigid horizontal bar is continuous so as to simulate a real contribution. Figure [8] shows an application of the Tridimensional Frame
Model to illustrate some of its features. In Figure [8a], walls and lintels are presented with their "full" cross sections. In Figure [8b], it is observed the three-dimensional vertical and horizontal bars, with their names. Analyzing the ends of the horizontal bars not collinear, it is noted that they have been articulated (the joint is represented by a green circle). It is also evident that the continuity between horizontal rigid bars and lintels was maintained (example: connecting the bar 102 to bar 5). There was also continuity in meeting vertical bars with horizontal bars (example: connecting the bar 1 with bars 101 and 102).

It is important to remember that as the wall is represented by a vertical bar which has the geometrical characteristics of the wall and horizontal bars having the same height and thickness of the wall and simulate its length, it is necessary to disregard the own weight of the horizontal bars. Otherwise, the weight of the wall would be counted twice.

In studies carried out in this work, it was multiplied by 100 the bending stiffness of the major inertia direction of the horizontal rigid bar in order to make them infinitely rigid in the plane of the wall.

The hypothesis of the slabs acting as a rigid diaphragm is also considered in the Tridimensional Frame Model. Thus, the initial and final nodes of the vertical bars are linked to the respective floor master node. Thus, in the six degrees of freedom at each end of the vertical bar, three are "slaves" to the master node of the floor, which are related to the two horizontal translations and rotation about the longitudinal axis of the vertical bar.

As previously mentioned, the Tridimensional Frame Model was developed by the finite element method in commercial software SAP2000. To represent the horizontal rigid bars and vertical flexible bars rigid bars, it was used the frame element from the library of elements of the program, which formulation is as Bathe e Wilson apud CSI [12]. The shear deformation is considered in this formulation, however, it was not considered in the horizontal rigid bars. The system of axes of the local frame element can be seen in Figure [9] and the degrees of freedom of a node element

Figure 9- Local axis system for the Frame element (CSI - SAP2000, 2011 (12))
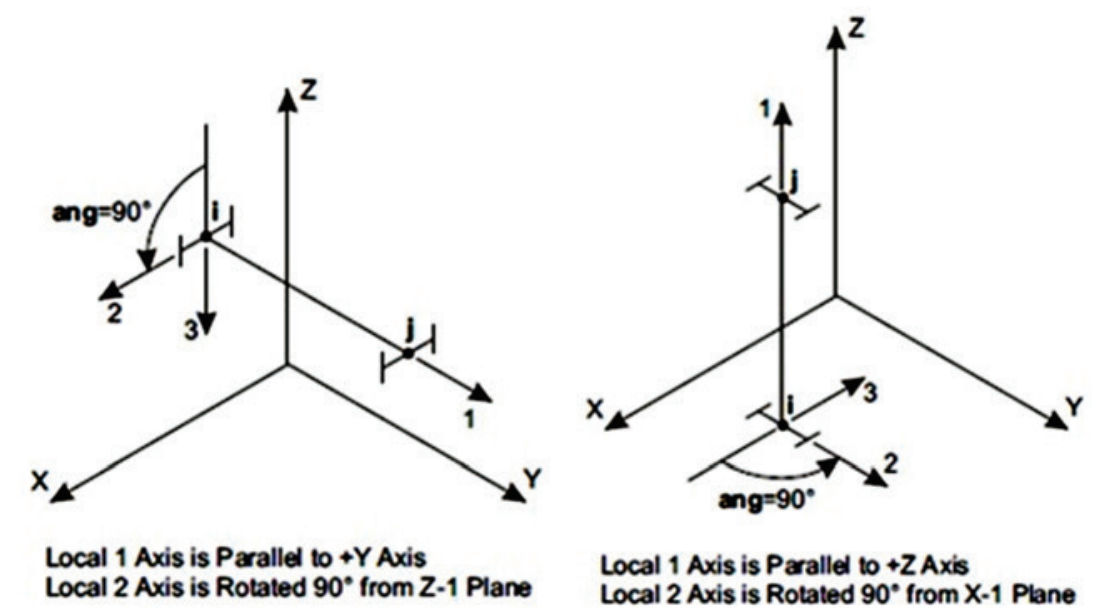

Local 1 Axis is Parallel to $+Z$ Axis

Local 2 Axis is Rotated $90^{\circ}$ from X-1 Plane 

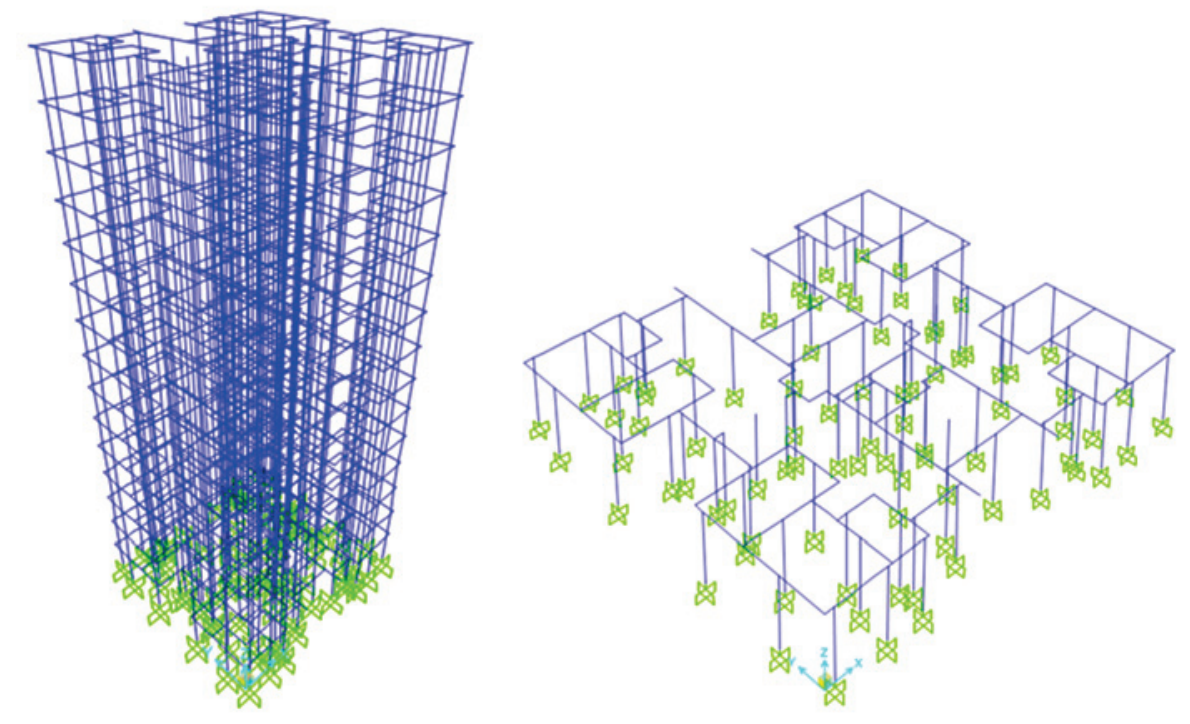

in Figure [5]. The Figure [10] shows the Tridimensional Frame Model applied to the studied building.

\subsection{Mechanical properties of concrete}

It was considered physical linearity to concrete material in both numerical model (MEF and MPT). The mechanical properties considered for the concrete material were: compression strength of $25 \mathrm{MPa}\left(25000 \mathrm{kN} / \mathrm{m}^{2}\right)$, secant modulus of elasticity $E=24000000 \mathrm{kN} / \mathrm{m}^{2}$, Poisson's ratio $V=0.2$ and a specific weight $\gamma^{c s}=250 \mathrm{kN} / \mathrm{m}^{3}$. The material was considered as isotropic.

\section{Results}

\subsection{Distribution of vertical loads}

Table [2] compares the normal concentrated forces only from the vertical load ( $N_{k, v e r t}$ ), obtained by MEF and MPT at the foundation level models. The cells painted in green mean that the difference in outcome of MPT compared to MEF is less than or equal, in absolute value, than $5 \%$, showing an excellent approximation. Those painted in yellow mean that the difference was obtained at all, greater than $5 \%$ and less than or equal to $15 \%$ range that describes the results as good value. Painted red cells show differences above $15 \%$ threshold at which the result is considered bad. The $15 \%$ limit which classifies the difference in results between calculation models as poor, was based on the coefficient $\gamma_{f 3}$ which considers the possible errors in the evaluation of the load effects, occurred by construction problems or by deficiency of the method of calculation employed. According to NBR 8681:2003 Actions and safety of structures - Procedures [3], when considering the ultimate limit states, the $\gamma_{f}$ coefficients can be considered as the product of $\gamma_{f 1}$, considering the variability of the actions and, $\gamma_{f 3}$ that can be adopted equal to 1.18 . This means that the accuracy of a model calculation can vary by up to $18 \%$ without the degree of safety of the structure is affected.

The approximation of results is very good, since $93 \%$ of the walls showed differences of less than $5 \%, 2 \%$ of the walls differences between $5 \%$ and $15 \%$, and only $5 \%$ of the walls showed poor result.

The walls PV14 and its symmetrical PV21, and the walls PH23 and its symmetrical PH24, showed differences of $N_{k, v e r t}$, between the two models analyzed, greater than $15 \%$ and up to $20.3 \%$. The wall $\mathrm{PH} 23$ interacts with the wall PV14, and the wall $\mathrm{PH} 24$ interacts with the wall PV21 in order to standardize the vertical loads. So, each pair of these walls forms a group of walls. Note that the group of walls PH23-PV14 and PV21-PH24, are connected through lintels to much larger groups of walls, which are located in the middle of the building.

The interaction between groups with high rigidity with groups of relative small stiffness, through just a lintel, may be the cause of the difference in results for these cases, however this hypothesis needs to be examined.

Another important factor, and that makes the MPT in favor of safety, is the fact that all the poor results in terms of normal concentrated force are higher than the normal concentrated forces obtained by MEF model. In order to show the verification of the maximum normal compressive stress, and avoid excessive results, it was decided to present the diagrams of internal forces of two shear walls in the horizontal direction (PH16 and $\mathrm{PH} 34)$ and two shear walls in vertical direction (PV08 and PV15).

Figure [11] shows the normal force diagrams, considering only the distribution of vertical loads, of the PH16, PH34, PV08 and PV15 walls. It is noted that a good approximation results between MPT and MEF models occurs along the entire height of the wall.

\subsection{Bending moment and normal force due to only horizontal actions}

The following are presented and compared the bending moment 


\section{Table 2 - Comparison of $N_{k, v e r t}$ at the foundation level}

\begin{tabular}{|c|c|c|c|c|c|c|c|c|c|c|}
\hline \multicolumn{10}{|c|}{ Distribution of vertical loads $-N_{k, v e r t}(k N)->t=12 \mathrm{~cm}$} & \\
\hline Wall & $L(m)$ & MEF & MPT & $\%$ & Wall & $L(m)$ & MEF & MPT & $\%$ & \\
\hline $\mathrm{PHOl}$ & 0,80 & 199,1 & 199,0 & 0,0 & $\mathrm{PH} 45$ & 0,80 & 201,0 & 199,9 & $-0,6$ & \\
\hline $\mathrm{PHO2}$ & 1,20 & 311,9 & 304,3 & $-2,4$ & $\mathrm{PH} 46$ & 1,20 & 315,1 & 306,3 & $-2,8$ & \\
\hline $\mathrm{PHO3}$ & 0,40 & 100,9 & 102,2 & 1,3 & $\mathrm{PH} 47$ & 0,40 & 102,2 & 103,1 & 0,9 & \\
\hline $\mathrm{PHO4}$ & 0,40 & 101,1 & 102,4 & 1,3 & $\mathrm{PH} 48$ & 0,40 & 102,1 & 102,2 & 0,1 & \\
\hline PHO5 & 1,20 & 313,0 & 306,0 & $-2,3$ & PH49 & 1,20 & 315,4 & 305,1 & $-3,2$ & \\
\hline $\mathrm{PHO6}$ & 0,80 & 200,6 & 201,3 & 0,3 & PH50 & 0,80 & 201,7 & 200,5 & $-0,6$ & \\
\hline PHO7 & 0,40 & 98,3 & 102,6 & 4,4 & PV01 & 4,00 & 1005,0 & 1000,9 & $-0,4$ & \\
\hline PH08 & 0,40 & 85,5 & 87,0 & 1,7 & PV02 & 0,80 & 203,8 & 202,7 & $-0,5$ & \\
\hline PHO9 & 0,40 & 86,0 & 87,7 & 1,9 & PV03 & 0,80 & 204,0 & 203,2 & $-0,4$ & \\
\hline $\mathrm{PH} 10$ & 0,40 & 98,3 & 102,7 & 4,4 & PV04 & 4,00 & 1000,1 & 999,4 & $-0,1$ & \\
\hline PHI 1 & 0,80 & 201,7 & 203,1 & 0,7 & PV05 & 0,40 & 98,9 & 103,7 & 4,9 & \\
\hline $\mathrm{PH} 12$ & 0,80 & 201,8 & 203,2 & 0,7 & PV06 & 0,80 & 213,5 & 209,3 & $-2,0$ & \\
\hline $\mathrm{PH} 13$ & 3,20 & 803,7 & 813,2 & 1,2 & PV07 & 0,40 & 99,1 & 103,9 & 4,8 & \\
\hline $\mathrm{PH} 14$ & 3,20 & 804,9 & 814,8 & 1,2 & PV08 & 2,80 & 716,4 & 714,1 & $-0,3$ & \\
\hline PH15 & 4,00 & 860,8 & 840,8 & $-2,3$ & PV09 & 2,80 & 710,6 & 710,0 & $-0,1$ & \\
\hline $\mathrm{PH} 16$ & 4,00 & 1020,7 & 1033,3 & 1,2 & PV10 & 2,40 & 621,0 & 635,3 & 2,3 & \\
\hline $\mathrm{PH} 17$ & 4,00 & 1020,8 & 1031,2 & 1,0 & PV11 & 2,40 & 620,1 & 635,1 & 2,4 & \\
\hline PH18 & 0,40 & 87,0 & 84,9 & $-2,4$ & PV12 & 2,40 & 607,8 & 619,3 & 1,9 & \\
\hline PHI9 & 0,80 & 188,0 & 185,0 & $-1,6$ & PV13 & 2,40 & 600,9 & 614,1 & 2,2 & \\
\hline $\mathrm{PH} 2 \mathrm{O}$ & 0,40 & 87,3 & 85,3 & $-2,2$ & PV14 & 1,60 & 391,7 & 463,8 & 18,4 & \\
\hline $\mathrm{PH} 21$ & 0,80 & 210,3 & 209,1 & $-0,6$ & PV15 & 7,20 & 1677,5 & 1605,0 & $-4,3$ & \\
\hline $\mathrm{PH} 22$ & 1,20 & 324,5 & 324,5 & 0,0 & PV16 & 7,20 & 1614,7 & 1513,0 & $-6,3$ & \\
\hline $\mathrm{PH} 23$ & 0,80 & 192,3 & 231,3 & 20,3 & PV17 & 2,00 & 445,8 & 444,6 & $-0,3$ & \\
\hline $\mathrm{PH} 24$ & 0,80 & 194,5 & 231,5 & 19,1 & PV18 & 0,40 & 93,4 & 89,2 & $-4,5$ & \\
\hline $\mathrm{PH} 25$ & 1,20 & 324,5 & 324,5 & 0,0 & PV19 & 7,20 & 1712,0 & 1656,8 & $-3,2$ & \\
\hline $\mathrm{PH} 26$ & 0,80 & 210,2 & 208,8 & $-0,7$ & PV20 & 7,20 & 1622,0 & 1523,8 & $-6,1$ & \\
\hline $\mathrm{PH} 27$ & 0,40 & 88,9 & 88,4 & $-0,6$ & PV21 & 1,60 & 395,6 & 463,6 & 17,2 & \\
\hline $\mathrm{PH} 28$ & 1,20 & 277,8 & 268,3 & $-3,4$ & PV22 & 2,40 & 607,1 & 614,4 & 1,2 & \\
\hline $\mathrm{PH} 29$ & 0,80 & 185,1 & 184,4 & $-0,4$ & PV23 & 2,40 & 601,5 & 614,1 & 2,1 & \\
\hline $\mathrm{PH} 30$ & 1,60 & 353,7 & 355,0 & 0,4 & PV24 & 2,40 & 619,0 & 631,8 & 2,1 & \\
\hline PH31 & 4,00 & 1019,5 & 1031,9 & 1,2 & PV25 & 2,40 & 617,9 & 631,1 & 2,1 & \\
\hline PH32 & 4,00 & 1022,5 & 1036,2 & 1,3 & PV26 & 2,80 & 717,2 & 712,4 & $-0,7$ & \\
\hline PH33 & 0,40 & 89,9 & 90,6 & 0,8 & PV27 & 2,80 & 712,3 & 712,1 & 0,0 & \\
\hline PH34 & 2,80 & 631,8 & 619,9 & $-1,9$ & PV28 & 0,40 & 99,1 & 104,0 & 4,9 & \\
\hline PH35 & 3,20 & 805,4 & 814,2 & 1,1 & PV29 & 0,80 & 213,6 & 209,2 & $-2,1$ & \\
\hline PH36 & 3,20 & 808,4 & 816,5 & 1,0 & PV30 & 0,40 & 99,0 & 103,5 & 4,6 & \\
\hline PH37 & 0,80 & 202,9 & 204,3 & 0,7 & PV31 & 4,00 & 1012,0 & 1008,7 & $-0,3$ & \\
\hline PH38 & 0,80 & 203,0 & 203,7 & 0,3 & PV32 & 0,80 & 205,5 & 205,3 & $-0,1$ & \\
\hline PH39 & 0,40 & 90,3 & 89,9 & $-0,5$ & PV33 & 0,80 & 205,0 & 204,0 & $-0,5$ & \\
\hline $\mathrm{PH} 40$ & 2,80 & 645,7 & 637,5 & $-1,3$ & PV34 & 4,00 & 1006,4 & 1008,4 & 0,2 & \\
\hline $\mathrm{PH} 4 \mathrm{l}$ & 0,40 & 99,4 & 103,7 & 4,4 & - & - & - & - & MPT & \\
\hline $\mathrm{PH} 42$ & 0,40 & 89,8 & 92,0 & 2,5 & - & - & - & - & $5 \%$ & \\
\hline $\mathrm{PH} 43$ & 0,40 & 91,7 & 93,6 & 2,2 & - & - & - & - & $2 \%$ & \\
\hline $\mathrm{PH} 44$ & 0,40 & 99,1 & 103,0 & 3,9 & - & - & - & - & $93 \%$ & \\
\hline
\end{tabular}


Figure 11 - Diagram of $\mathrm{N}_{k, \text { vert }}$ of the walls PH16, PH34, PV08 and PV15

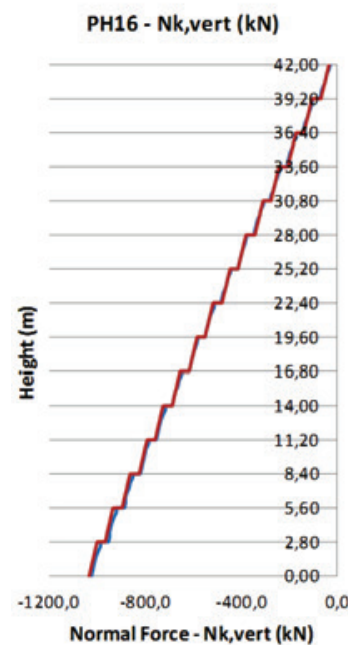

-MEF - Nk,vert

-MPT - Nk,vert
PH34 - Nk,vert (kN)

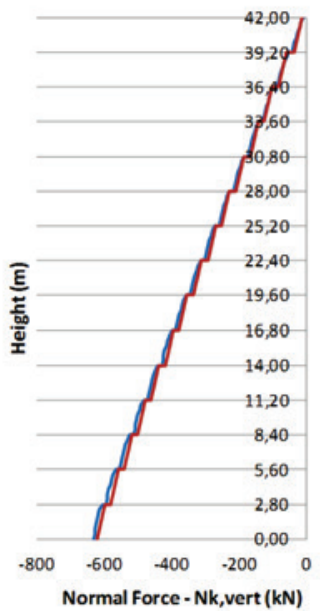

-MEF-Nk,vert
PV08 - Nk,vert (kN)

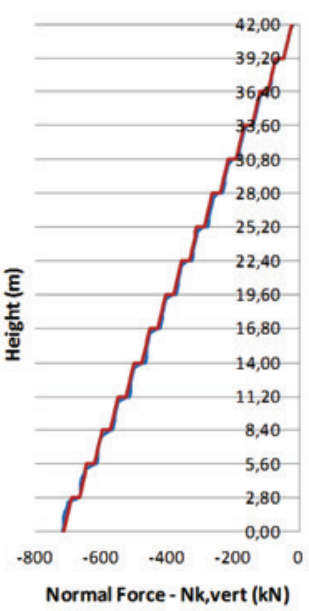

-MEF - Nk,vert
PV15 - Nk,vert (kN)

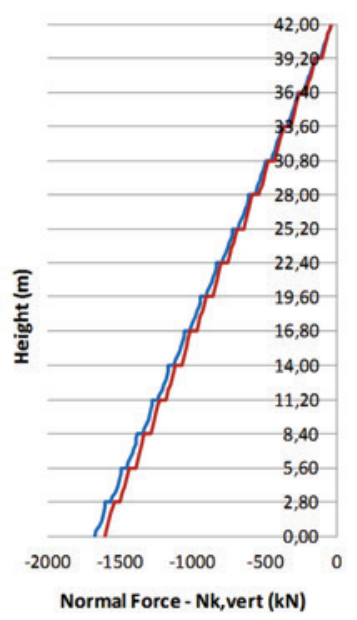

-MEF - Nk,vert diagrams and normal force obtained by MEF and MPT models, of the PH16, PH34, PV08 and PV15 walls, considering only horizontal actions.

Following the vector notation and the directions of the global coordinate axis, shown in Figure [2], the results for $\mathrm{PH} 16$ and $\mathrm{PH} 34$ walls are characteristic bending moments in the $Y$ direction $\left(M_{k, y}\right)$ and the PV08 and PV15 walls are characteristic bending moments in the X direction $\left(M_{k, x}\right)$.

The characteristic bending moment diagrams shown in Figure [12] show that the MPT model tends to the behavior of the MEF, however make it clear that there are considerable differences in results. Table [3] compares the largest bending moments obtained on the walls analyzed. In all cases, the cross-section at the foundation level $0,00 \mathrm{~m}$ section was the one with the highest value of bending moment. Note that there are differences of up to $56,21 \%$ as in the case of PH34 wall.

While models present similar behavior, analyzing the normal forces diagrams in Figure [13], highlights the difference in nature between the bar model (MPT) and the models of shells (MEF). In the shell model, the wall is represented throughout its height, making the internal forces and interaction walls are better represented. The model of bars represented each wall with only one vertical bar per floor and horizontal bars to simulate the interaction between them, i.e. is a much simpler model.

The normal forces from only horizontal actions in MPT are constant in each leg of the walls, unlike what happens in MEF, where the distribution of this internal force is not constant. This is justified, because in the shell model, the interaction between the walls occurs throughout the entire height of the deck through the nodal displacements compatibility. In the bar model this simulation is

Figure 12 - Diagram of $\mathrm{M}_{k, y}$ of the walls PH 16 and PH34 and $\mathrm{M}_{k, x}$ of the walls PV08 and PV15

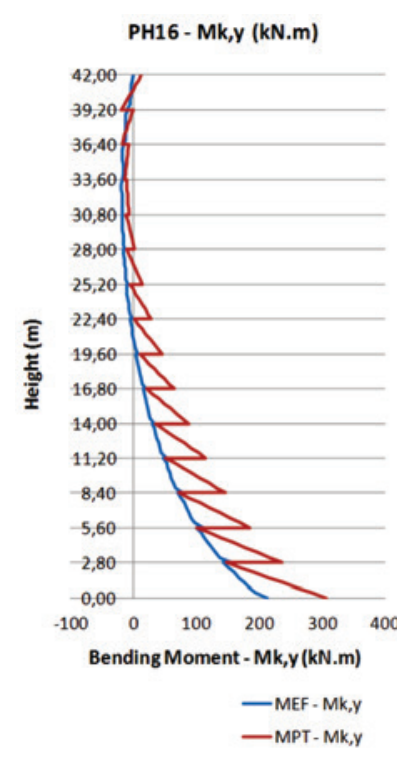

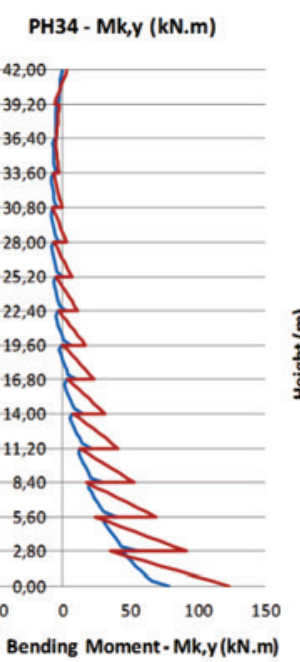

- $\mathrm{MEF} \cdot \mathrm{Mk}, \mathrm{y}$

- MPT $\cdot M k, y$
PV08 - Mk,X (kN.m)

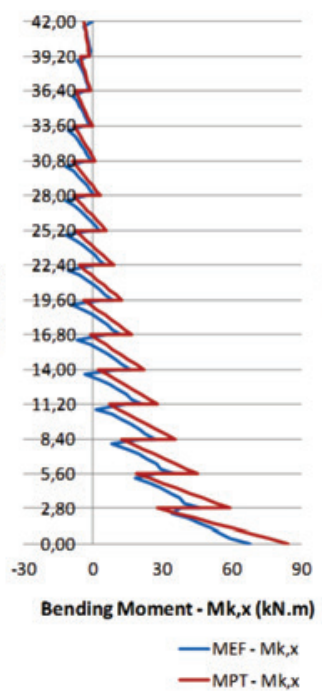

PV15 - Mk,x (kN.m)

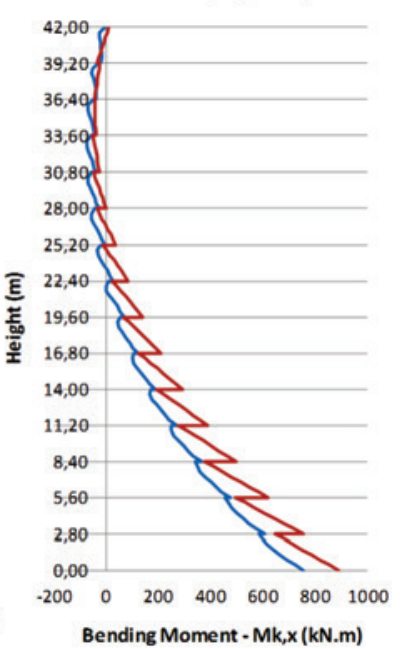

- MEF - Mk,x 
summarized with one nodal force applied to the level floor, at the meeting of the horizontal rigid bars.

Table [4] shows the difference of the maximum normal force obtained by MEF and MPT models. In the case of the wall PH34 difference reaches $63.05 \%$.

\subsection{Maximum normal stress of compression}

To design a concrete wall of a building it is used the method of limit states which is based on probabilistic methods that take into account the variability of actions and resistances through combinations of actions and weighting coefficients to obtain the values of design. It can be used a combination of actions $\mathrm{C} 1$ shown in Equation [6] to afford the internal forces that generate the most unfavorable condition for the normal stress of compression for a given cross-section. The weighting coefficients were adopted as shown in NBR 16055 [4].

Table 3 - Comparison of maximum bending moments in the walls analyzed

\begin{tabular}{cccccc}
\multicolumn{7}{c}{ Comparison of Mk $(\mathrm{kN} . \mathrm{m})$ obtained by MEF and MPT models } \\
Wall & Internal Force & level $(\mathrm{m})$ & MEF & MPT & $\%$ \\
PH16 & Mk,y & 0,00 & 213,68 & 306,02 & 43,21 \\
PH34 & Mk,y & 0,00 & 78,96 & 123,34 & 56,21 \\
PV08 & Mk, & 0,00 & 67,71 & 84,39 & 24,64 \\
PV15 & Mk, & 0,00 & 754,70 & 889,02 & 17,80 \\
\hline
\end{tabular}

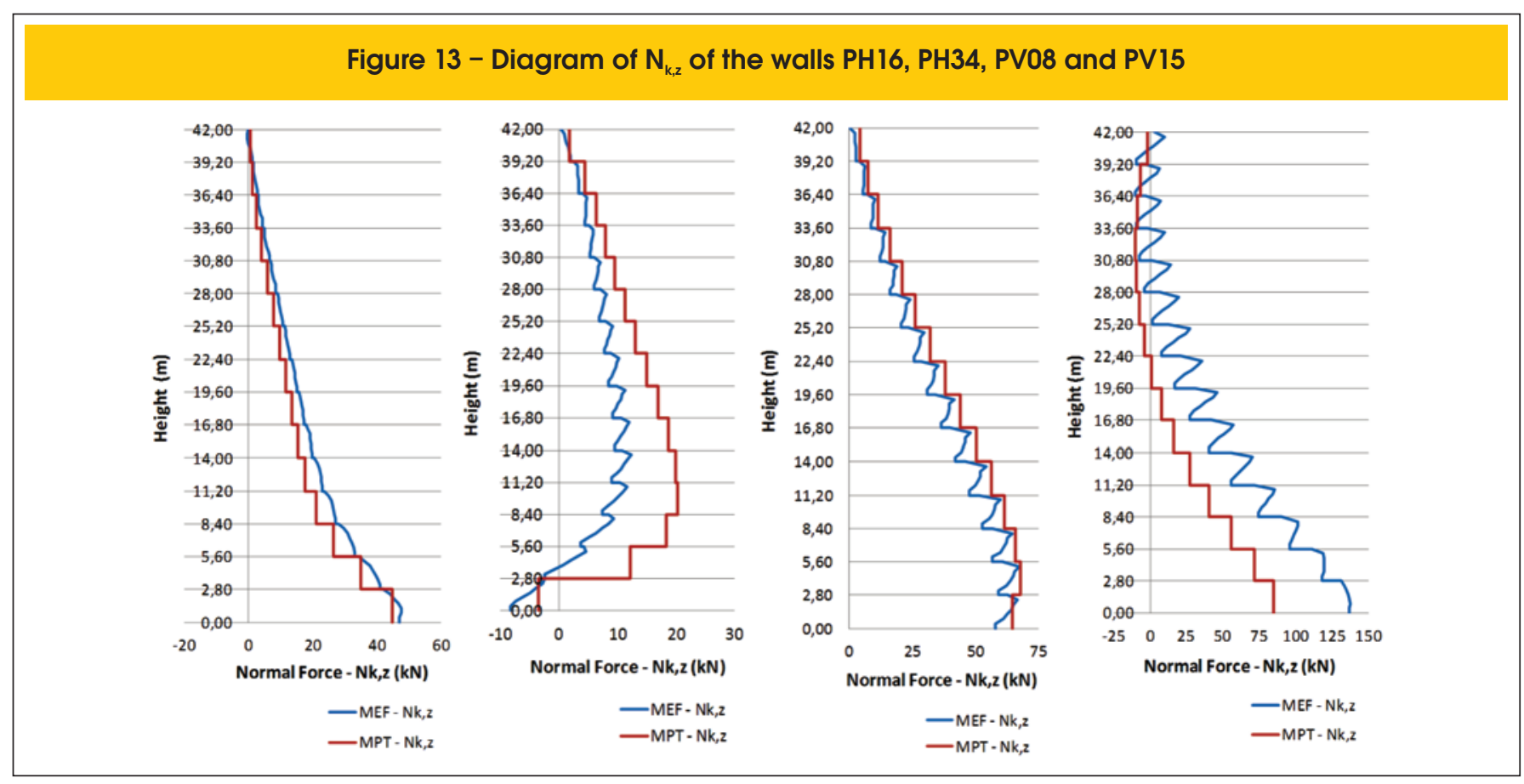

Table 4 - Comparison of the maximum normal forces on the walls analyzed

\begin{tabular}{|ccccccc}
\multicolumn{7}{c}{ Comparison of Nk $(\mathrm{kN})$ obtained by MEF and MPT models } \\
Wall & Internal Force & level $(\mathrm{m})$ & MEF & MPT & $\%$ \\
PH16 & Nk, & 0,80 & 47,61 & 44,88 & $-5,74$ \\
PH34 & $\mathrm{Nk}, \mathrm{z}$ & 13,60 & 12,30 & 20,05 & 63,05 \\
PV08 & $\mathrm{Nk}, \mathrm{z}$ & 5,20 & 67,41 & 67,90 & 0,72 \\
PV15 & $\mathrm{Nk}, \mathrm{z}$ & 0,80 & 137,94 & 84,93 & $-38,43$ \\
\hline
\end{tabular}


Figure 14 - Diagram of $\mathrm{M}_{\mathrm{cd}, \mathrm{y}}$ of the walls PH16 and PH34 and $\mathrm{M}_{\mathrm{cd}, \mathrm{x}}$ of the walls PV08 and PV15
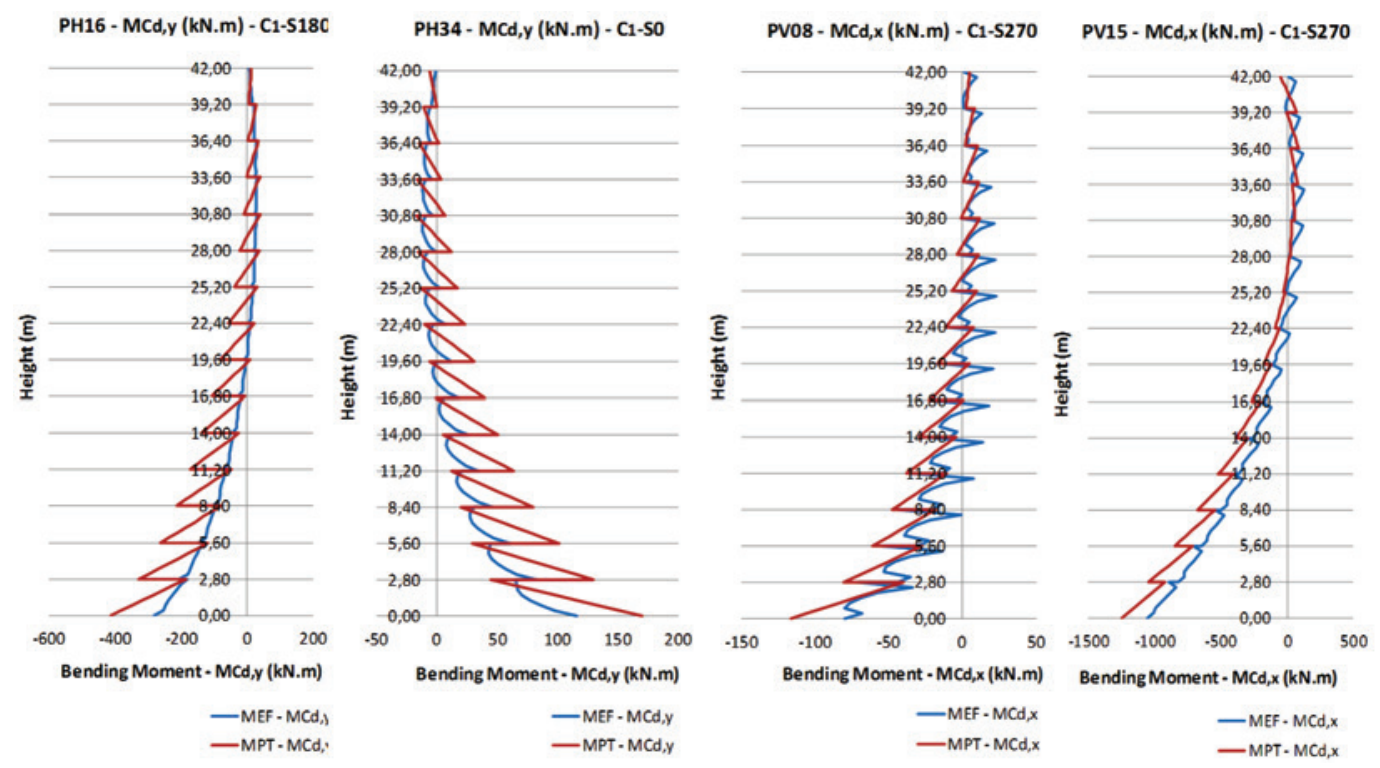

Onde:

$F_{d}$ internal force that provides de maximum stress of compression; $P$ : self-weight of structural elements;

$G_{S L A B}$ : coating considered on the slabs;

$Q_{W I N D}$ : wind action toward the bracing wall;

$Q_{S L A B}:$ live load on the slabs as the NBR 6120;

$Q_{P L U M B}$ : out of plumb action in the same direction as the wind action. When checking the normal compressive stress of a concrete wall, it is necessary to compose the internal forces made by the vertical loads (normal force), and the internal forces made by the horizontal loads (bending moment and normal force) as Equation [7].

$$
\sigma_{C d}=\frac{N_{C d}}{A} \pm \frac{M_{C d}}{W}
$$

Where:

$\sigma_{\text {, }}$ : normal stress for the condition to the maximum compression; $N_{d d}$ : normal force that provides the maximum compression;

$M_{c d}^{c d}:$ : bending moment that provides the maximum compression; $A$ : area of the cross section of the wall;

$W$ : flexural modulus.

Figures [14] and [15] show diagrams of $M_{c d}$ and $N_{c d}$ of the walls analyzed, respectively.

Table [5] compares the differences obtained between the MPT and MEF models, characteristic of the maximum characteristic bending moments calculated considering only horizontal actions, and the maximum design bending moment, considering the combination of actions $\mathrm{C} 1$, showing the level where they occur, and the percentage difference. Since the bending moment is practically influenced only by horizontal actions, the magnitude of the differences ob-

Figure 15 - Diagram of $\mathrm{N}_{\mathrm{cd}, 2}$ of the walls PH16, PH34, PV08 and PV15
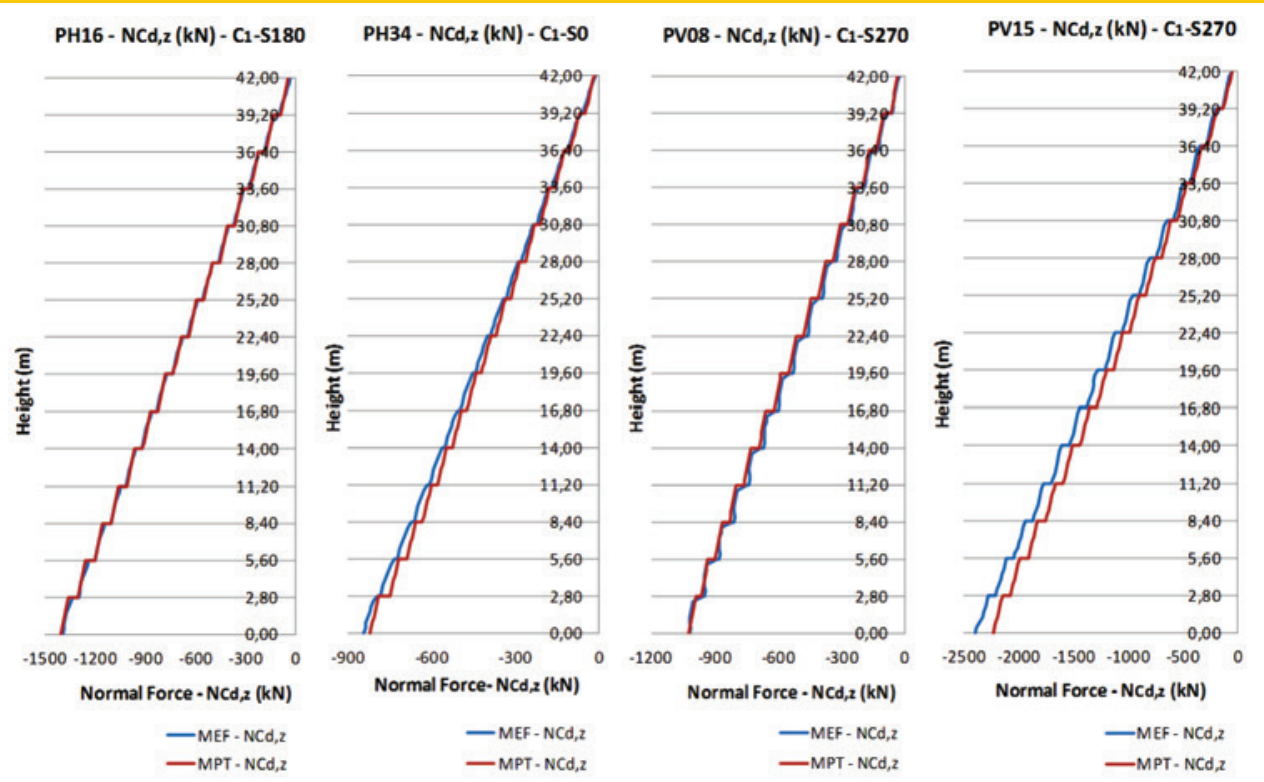
tained when comparing the characteristic values and the design ones, is almost the same.

Table [6] compares the differences obtained between the MPT and MEF models, of the maximum characteristics normal force calculated considering only horizontal actions, and the maximum design normal forces, considering the combination of actions $\mathrm{C} 1$, showing the level where they occur, and the percentage difference.

Observe in the title of bending moment diagrams, normal force and design stress of compression, the direction in which the horizontal actions are more unfavorable to the internal forces of the respective wall bracing. For example, the wall $\mathrm{PH} 16$, has the horizontal actions in the $\mathrm{X}$ direction in the $180^{\circ}$ because it provides the most unfavorable values for the bending moment $M_{a, y}$.
The results in Table [6] show that when the normal forces from horizontal actions are combined with normal forces from the vertical loads, the differences between MPT and MEF models are reduced significantly with results very close. This is because, as seen in the diagrams of Figure [11], the differences between the models are very small when compared the normal forces from vertical loads only. Also they are much larger when compared with the normal forces obtained only by horizontal actions.

With design bending moments and design normal forces presented, the normal stress diagram of the cross section, at the foundation level, which is critical in all walls analyzed here, is plotted as Figures [16] and [17].

\section{Table 5 - Comparison of the maximum $\mathrm{M}_{\mathrm{k}, \mathrm{y}}$, and $\mathrm{M}_{\mathrm{cd}, \mathrm{y}}$, on the walls $\mathrm{PH} 16$ and $\mathrm{PH} 34$ and the maximum $M_{k, x}$, and $M_{c d, x}$, on the walls PV08 and PV15}

\begin{tabular}{|c|c|c|c|c|c|c|c|c|}
\hline \multirow[b]{2}{*}{ WALL } & \multicolumn{4}{|c|}{$\mathrm{M}_{\mathrm{k}, \mathrm{y}}(\mathrm{kN} \cdot \mathrm{m})$} & \multicolumn{4}{|c|}{$\mathrm{M}_{\mathrm{cd}, \mathrm{y}}(\mathrm{kN} \cdot \mathrm{m})$} \\
\hline & level (m) & MEF & MPT & $\%$ & level (m) & MEF & MPT & $\%$ \\
\hline $\mathrm{PH} 16$ & 0,00 & 213,68 & 306,02 & 43,21 & 0,00 & $-280,94$ & $-411,90$ & 46,62 \\
\hline PH34 & 0,00 & 78,96 & 123,34 & 56,21 & 0,00 & 115,65 & 169,79 & 46,81 \\
\hline & \multicolumn{4}{|c|}{$M_{k, x}(k N . m)$} & \multicolumn{4}{|c|}{$\mathrm{M}_{\mathrm{cd}, \mathrm{x}}(\mathrm{kN} \cdot \mathrm{m})$} \\
\hline WALL & level (m) & MEF & MPT & $\%$ & level (m) & MEF & MPT & $\%$ \\
\hline PV08 & 0,00 & 67,71 & 84,39 & 24,64 & 0,00 & $-79,88$ & $-116,35$ & 45,65 \\
\hline PV15 & 0,00 & 754,70 & 889,02 & 17,80 & 0,00 & $-1050,08$ & $-1245,33$ & 18,59 \\
\hline
\end{tabular}

Table 6 - Comparison of the maximum $\mathrm{N}_{\mathrm{k}, 2}$, and $\mathrm{N}_{\mathrm{cd}, 2}$, on the walls PH16, PH34, PV08 and PV15

\begin{tabular}{|c|c|c|c|c|c|c|c|c|}
\hline \multirow[b]{2}{*}{ WALL } & \multicolumn{4}{|c|}{$\mathbf{N}_{\mathrm{k}, \mathrm{z}}(\mathbf{k N})$} & \multicolumn{4}{|c|}{$\mathbf{N}_{\mathrm{cd}, \mathrm{z}}(\mathbf{k N})$} \\
\hline & level $(m)$ & MEF & MPT & $\%$ & level $(m)$ & MEF & MPT & $\%$ \\
\hline $\mathrm{PH} 16$ & 0,80 & 47,61 & 44,88 & $-5,74$ & 0,00 & $-1396,43$ & $-1409,39$ & 0,93 \\
\hline PH34 & 13,60 & 12,30 & 20,05 & 63,05 & 0,00 & $-842,11$ & $-821,33$ & $-2,47$ \\
\hline PV08 & 5,20 & 67,41 & 67,90 & 0,72 & 0,00 & $-1016,63$ & $-1022,93$ & 0,62 \\
\hline PV15 & 0,80 & 137,94 & 84,93 & $-38,43$ & 0,00 & $-2393,01$ & $-2230,87$ & $-6,78$ \\
\hline
\end{tabular}

Figure 16 - Diagram of $\sigma_{\mathrm{Cd}}$ of the walls $\mathrm{PH} 16$ and PH34

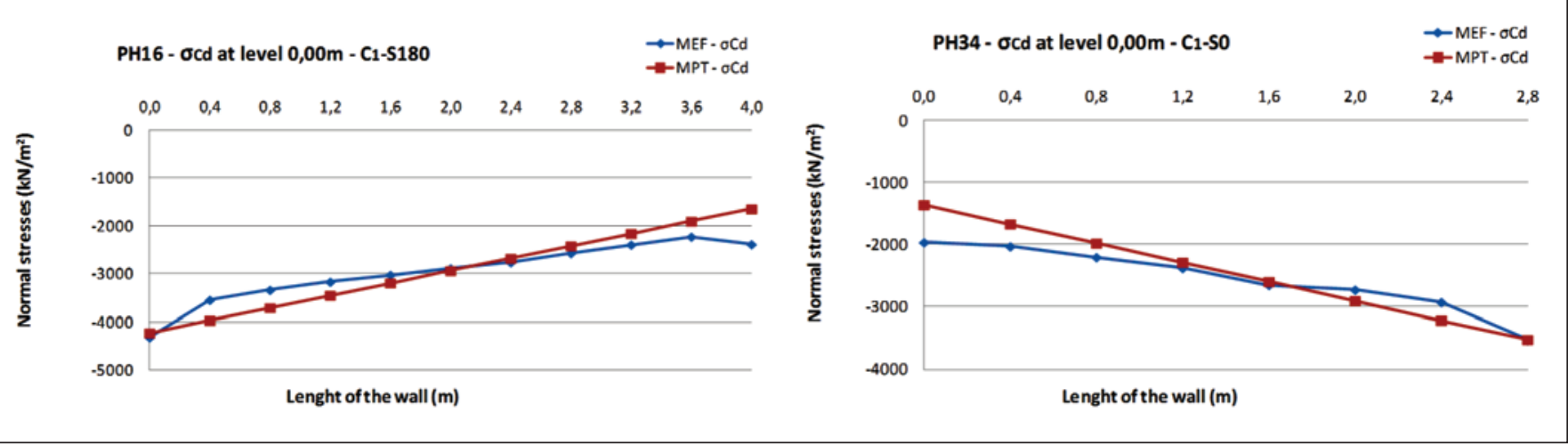




\section{Figure 17 - Diagram of the $\sigma_{\mathrm{Cd}}$ of the walls PV08 and PV15}

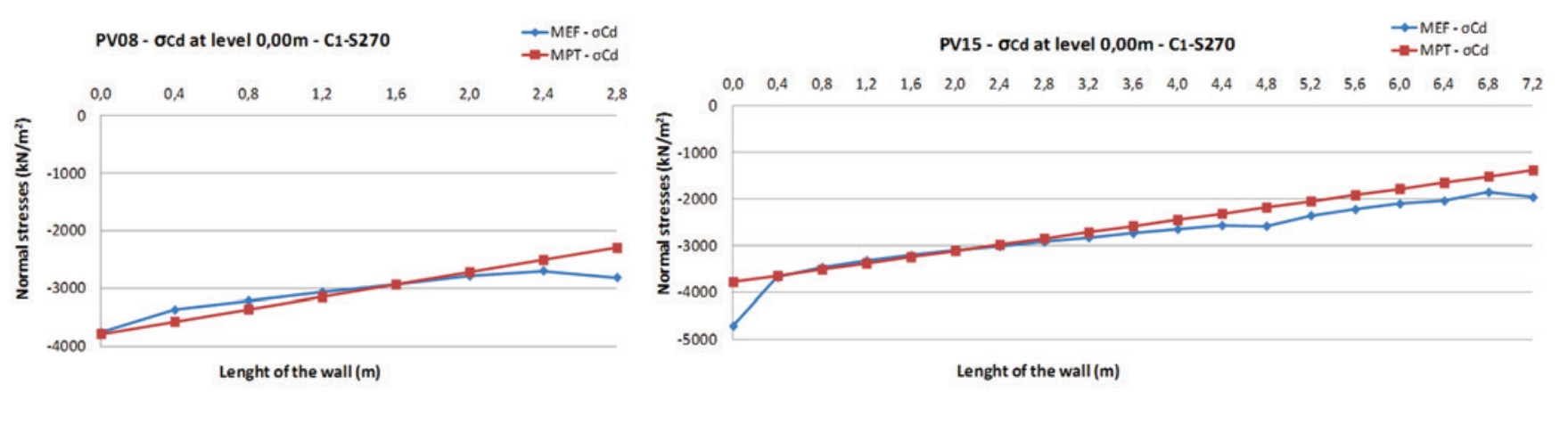

\begin{tabular}{|lcccc|}
\hline $\begin{array}{l}\text { Table } 7 \text { - Comparison of the maximum normal } \\
\text { stress of compression obtained by both models }\end{array}$ \\
\hline \multicolumn{5}{c}{$\sigma_{\text {Cd,max }}\left(\mathrm{kN} / \mathrm{m}^{2}\right)-\mathbf{C l}$} \\
WALLS & level $(\mathrm{m})$ & MEF & MPT & $\%$ \\
PH16 & 0,00 & $-4315,92$ & $-4223,43$ & $-2,14$ \\
PH34 & 0,00 & $-3531,92$ & $-3527,27$ & $-0,13$ \\
PV08 & 0,00 & $-3762,75$ & $-3786,43$ & 0,63 \\
PV15 & 0,00 & $-4716,17$ & $-3783,15$ & $-19,78$ \\
\hline
\end{tabular}

It is noteworthy the quality of MPT by its proximity from MEF, checked in the normal stresses diagrams. The maximum compressive stress compared in Table [7] reinforce this fact. The largest difference occurs in the wall PV15, where the compressive stress obtained by MPT is $19,78 \%$ lower than the one obtained by MEF. This comparison is made at the point where the cross section of the wall is more compressed. Comparing the distribution of normal stresses along the entire section of the wall PV15, this difference falls and gets close to zero at various points, as shown in the diagram in Figure [17]. The normal maximum compressive stress in the other walls have very similar results between the two models. The largest difference is 2,14\% (obtained after the wall PV15) and $0,13 \%$ is the lower.

\subsection{Design verification for the maximum stress of compression}

The design verification for the maximum stress of compression is done as procedures of NBR 16055 [4]. The maximum stress obtained should be lower than the ultimate stress of compression. The last one is calculated dividing the ultimate strength by the thickness of the wall. The ultimate strength of compression of the wall is calculated as the expression of item 17.5.1 from NBR 16055 [4], presented in Equation [8] :

$$
\begin{aligned}
& \eta_{d, r e s i s t}=\frac{\left(0,85 \cdot f_{c d}+\rho \cdot f_{s c d}\right) \cdot t}{k_{1}\left[1+3 k_{2}\left(2-k_{2}\right)\right]} \leq \\
& \frac{\left(0,85 \cdot f_{c d}+\rho \cdot f_{s c d}\right) \cdot t}{1,643} \leq 0,4 \cdot f_{c d} \cdot t
\end{aligned}
$$

Figure 18 - Calculation of $\ell_{e}$ as the type of bracing walls (NBR 16055:2012 (4))

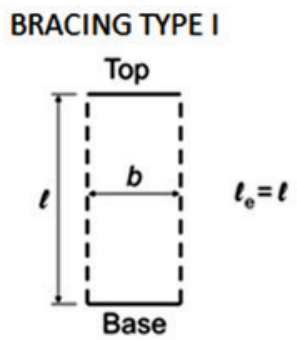

BRACING TYPE III

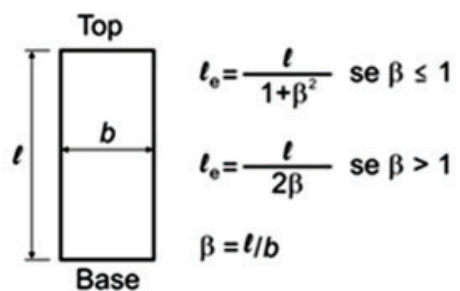

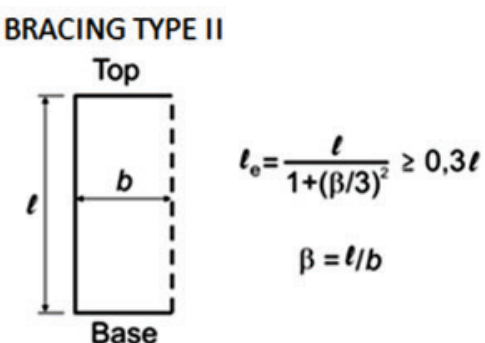

\section{BRACING TYPE IV}

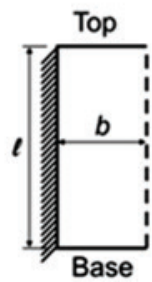

$\ell_{\mathrm{e}}=2 b \leq \ell$ 
Figure 19 - Decrease of the ultimate stress of compression with increasing slenderness ratio, according to NBR 16055 (4)

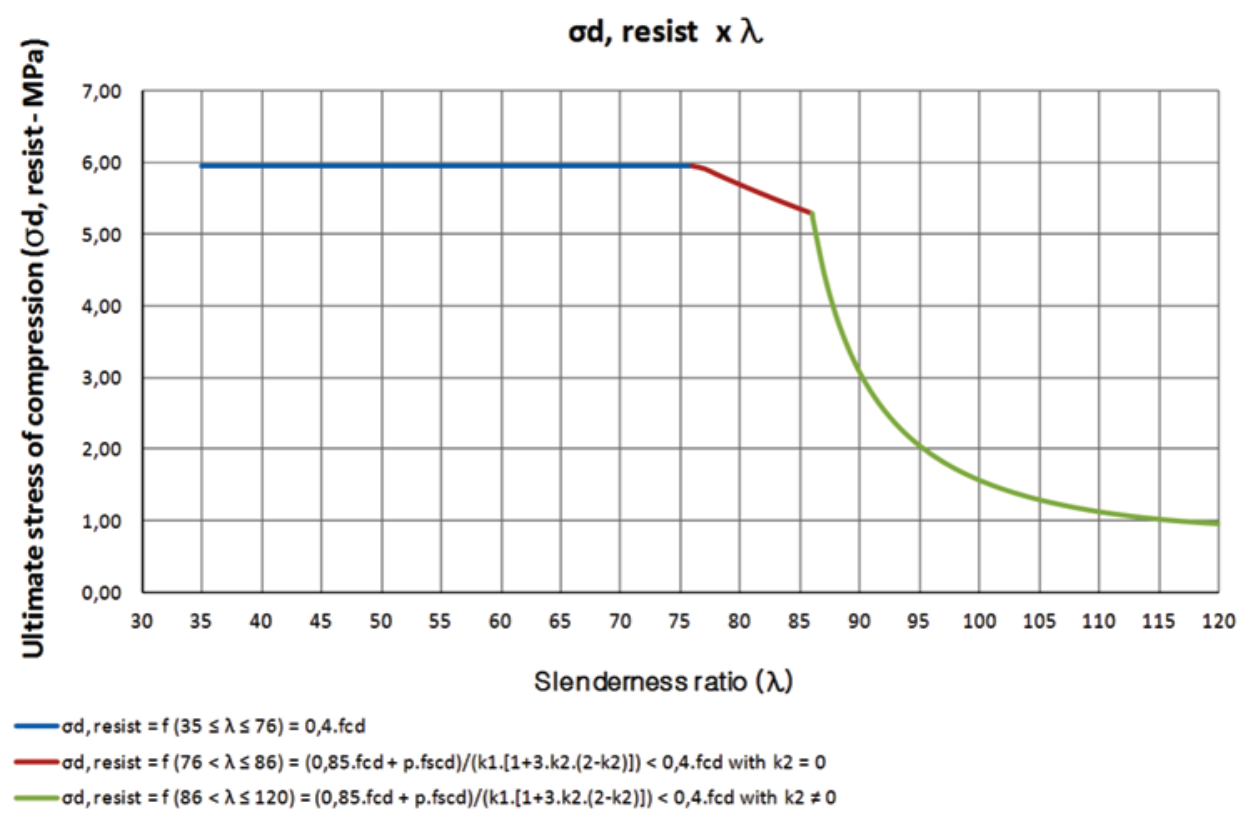

Where:

$\eta_{d, \text { resist }}:$ ultimate strength of compression;

$f_{c d}$ : design compressive strength of concrete;

$\rho$ : ratio of vertical reinforcement not bigger than $1 \%$;

$t:$ thickness of the wall;

$E_{s}:$ modulus of elasticity of the steel;

$\gamma_{s}$ : reduction coefficient of resistance of steel equal to 1,15 ;

The definition of the coefficients $k_{1}$ and $k_{2}$ depends on the slenderness ratio of the wall, which is defined by Equation [9].

$$
\lambda=\frac{\ell_{e} \cdot \sqrt{12}}{t}
$$

Figure 2 of NBR 16055 [4], presented here in Figure [18] in an adapted form, defines the equivalent length of the wall, depending on their bracings.

The coefficient $k_{1}$ is defined to $k_{1}=\lambda / 35$ for any value of $\lambda$. When the slenderness ratio is in the range $35 \leq \lambda \leq 86, k_{2}$ is equal to zero. If the slenderness ratio is in the range $86<\lambda \leq 120$, $k_{2}$ is defined by Equation [10].

$$
k_{2}=\frac{(\lambda-86)}{120}
$$

The coefficients $k_{1}$ and $k_{2}$ consider the penalization in the ultimate strength of compression due to the instability caused by localized effects of 2 nd order. To get magnitude, the graph of Figure

\begin{tabular}{|c|c|c|c|c|c|c|c|c|c|c|}
\hline \multirow[b]{2}{*}{ WALLS } & \multirow[b]{2}{*}{ Bracings } & \multirow[b]{2}{*}{$L(m)$} & \multicolumn{8}{|c|}{ Ultimate strength of compression - NBR $16055->t=12 \mathrm{~cm}$} \\
\hline & & & $\beta=h / L$ & $h_{e}(m)$ & $h_{\mathrm{e}} / \mathrm{t}$ & $\Lambda$ & k1 & k2 & $\eta_{\mathrm{d}, \text { essist }}(\mathrm{kN} / \mathrm{m})$ & $\sigma_{\mathrm{d}, \text { resist }}\left(\mathrm{kN} / \mathrm{m}^{2}\right)$ \\
\hline PH16a & III & 2,4 & 1,17 & 1,20 & 10,0 & 34,6 & 0,99 & 0,00 & 714,29 & 5952,38 \\
\hline $\mathrm{PH} 16 \mathrm{~b}$ & III & 1,6 & 1,75 & 0,80 & 6,7 & 23,1 & 0,66 & 0,00 & 714,29 & 5952,38 \\
\hline $\mathrm{PH} 34 \mathrm{a}$ & III & 1,6 & 1,75 & 0,80 & 6,7 & 23,1 & 0,66 & 0,00 & 714,29 & 5952,38 \\
\hline $\mathrm{PH} 34 \mathrm{~b}$ & $\|$ & 1,2 & 2,33 & 1,74 & 14,5 & 50,4 & 1,44 & 0,00 & 714,29 & 5952,38 \\
\hline PV08a & III & 2,4 & 1,17 & 1,20 & 10,0 & 34,6 & 0,99 & 0,00 & 714,29 & 5952,38 \\
\hline PV08b & $\|$ & 0,4 & 7,00 & 0,84 & 7,0 & 24,2 & 0,69 & 0,00 & 714,29 & 5952,38 \\
\hline PV15a & $\|$ & 0,8 & 3,50 & 1,19 & 9,9 & 34,2 & 0,98 & 0,00 & 714,29 & 5952,38 \\
\hline PV15b & III & 0,8 & 3,50 & 0,40 & 3,3 & 11,5 & 0,33 & 0,00 & 714,29 & 5952,38 \\
\hline PV15c & III & 3,2 & 0,88 & 1,59 & 13,2 & 45,8 & 1,31 & 0,00 & 714,29 & 5952,38 \\
\hline PV15d & III & 1,6 & 1,75 & 0,80 & 6,7 & 23,1 & 0,66 & 0,00 & 714,29 & 5952,38 \\
\hline PV15e & III & 0,4 & 7,00 & 0,20 & 1,7 & 5,8 & 0,16 & 0,00 & 714,29 & 5952,38 \\
\hline PV15f & $\|$ & 0,4 & 7,00 & 0,84 & 7,0 & 24,2 & 0,69 & 0,00 & 714,29 & 5952,38 \\
\hline
\end{tabular}

Table 8 - Calculation of the ultimate strength of compression as NBR 16055 (4) 
Table 9 - Verification of the design to the maximum normal stress of compression as NBR 16055 (4)

\begin{tabular}{|c|c|c|c|c|c|c|}
\hline \multirow[b]{2}{*}{ WALLS } & \multicolumn{4}{|c|}{$\sigma_{\mathrm{cd}, \max }\left(\mathrm{kN} / \mathrm{m}^{2}\right)-\mathrm{Cl}_{1}$} & \multirow{2}{*}{$\begin{array}{c}\sigma_{\mathrm{d}, \text { resist }}\left(\mathrm{kN} / \mathrm{m}^{2}\right) \\
\text { NBR 16055:2012 }\end{array}$} & \multirow{2}{*}{ STATUS } \\
\hline & level $(m)$ & MEF & MPT & $\%$ & & \\
\hline PH13 & 0,00 & $-3764,92$ & $-4006,79$ & 6,42 & $-5952,38$ & OK \\
\hline $\mathrm{PH} 16$ & 0,00 & $-4315,92$ & $-4223,43$ & $-2,14$ & $-5952,38$ & OK \\
\hline PV08 & 0,00 & $-3762,75$ & $-3786,43$ & 0,63 & $-5952,38$ & OK \\
\hline PV12 & 0,00 & $-3928,58$ & $-3711,41$ & $-5,53$ & $-5952,38$ & OK \\
\hline PV15 & 0,00 & $-4716,17$ & $-3783,15$ & $-19,78$ & $-5952,38$ & OK \\
\hline
\end{tabular}

[19] shows the decrease in the ultimate stress of compression as the slenderness ratio increases, where as $f_{c k}=25 \mathrm{MPa}$, $f_{\text {scd }}=365,2 \mathrm{MPa}$ and $\rho=0,1 \%$. When plotting the graph, the expression of the ultimate strength of compression, as described in Equation [8], is applied without considering the thickness of the wall so that the values stay in terms of stress. The loss of strength is visible and significant when $\lambda>86$, the threshold from which $k_{2}$ it is nonzero and that, consequently, the influence of localized instability is much larger. If it is wanted to make a more precise analysis of local and localized instabilities, the expressions of items 15.8 and 15.9 of NBR 6118 [1] should be used.

The ultimate strength of compression of the PH16, PH34, PV08 and PV15 walls are shown in Table [8] by portions represented by the letters a, b, c, etc.. that consider the change caused by bracing of the side walls transverse to them. Consequently, the length of these walls is given by portions and defined by transverse walls.

Finally Table [9] presents the verification of the design of the most requested cross section of the walls PH16, PH34, PV08 and PV15, for the compressive stress, according to the assumptions of the standard NBR 16055 [4].

Finally, it has been found that the initially thickness of $12 \mathrm{~cm}$ for the analyzed walls of the studied building are sufficient to resist the normal stresses of compression. This result is valid for both numerical models adopted (MPT and MEF).

\section{Conclusions}

The comparison between the results obtained by MEF and MPT models was done in order to evaluate them qualitatively when applied to the design concrete walls for the maximum normal stress of a building.

It was found an excellent approximation between MPT and MEF models for distributing vertical loads. The normal force concentrated at the foundation level coming from only vertical loads showed very similar results.

The diagrams of bending moments and normal forces, considering only the forces due to wind and out of plumb forces were traced. It was observed significant differences between the values obtained by MEF and MPT models. The bending at the foundation level of PH34 wall differed between models in 56,21\%. The same occurred with the maximum normal force obtained for this wall, which arrived at $63,05 \%$ difference. In spite of the differences in the results of these two internal forces, the curves of the diagrams were nearby and tended to the same conduct.
The differences checked between MEF and MPT when bending moments and normal forces (obtained from horizontal actions only) was compared, became insignificant when the design of de maximum normal stress of compression was done. Therefore, it was necessary to combine the vertical and horizontal loads.

When the composition of the design normal force calculation with the design bending moment was taken as the combination of actions $\mathrm{C} 1$, the values of normal stress obtained by the two models were very close. In the case of $\mathrm{PH} 34$ wall, the difference between the two models related to the maximum normal stress of compression was only $0,13 \%$. The diagrams of the normal stresses, plotted in the critical cross section of the other walls also showed the proximity between models. This similarity of stresses was justified by the close proximity obtained in normal forces arising only from vertical loads. Furthermore, due to the normal forces from vertical loads were much higher than those internal forces obtained by horizontal loads.

The maximum normal stress of compression has always been lower than the ultimate strength of compression calculated by NBR 16055 [4], considering the walls with $12 \mathrm{~cm}$ of thickness, which therefore satisfy the minimum condition for the design.

Therefore, it is concluded that the Tridimensional Frame Model can be used in the structural analysis of buildings constructed in the concrete wall system. The MPT proved a reliable model for the proximity of results when compared with MEF. The analysis of results via MEF is complicated, making it a tool not often used in everyday life of an office. The use of MEF is recommended for local analyzes and for situations that requires more details.

\section{References}

[01] ASSOCIAÇÃO BRASILEIRA DE NORMAS TÉCNICAS (2007) NBR 6118. Projeto de estrutura de concreto - Procedimentos. Rio de Janeiro, 2007.

[02] ASSOCIAÇÃO BRASILEIRA DE NORMAS TÉCNICAS (1980) NBR 6120. Cargas para o cálculo de estruturas de edificações. Rio de Janeiro, 1980.

[03] ASSOCIAÇÃO BRASILEIRA DE NORMAS TÉCNICAS (2003) NBR 8681. Ações e segurança nas estruturas - Procedimentos. Rio de Janeiro, 2003.

[04] ASSOCIAÇÃO BRASILEIRA DE NORMAS TÉCNICAS (2012) NBR 16055. Parede de concreto moldada no local para a construção de edificações - Requisitos e procedimentos. Rio de Janeiro, 2012. 
[05] ASSOCIAÇÃO BRASILEIRA DE NORMAS TÉCNICAS (2012) NBR 6123. Forças devidas ao vento em edificações. Rio de Janeiro, 2012.

[06] CORREAA, M. R. S. (2003). Fluxo de forças em edifícios de alvenaria estrutural. 156f. Texto apresentado para o concurso de Professor Livre Docente do departamento de Engenharia de Estruturas da Escola de Engenharia de São Carlos, Universidade de São Paulo, 2003.

[07] CORREAA, M.R.S.; RAMALHO, M.A.. Projeto de edifícios de alvenaria estrutural. São Paulo: Editora PINI Ltda, 2003.

[08] NASCIMENTO NETO, J. A. (1999). Investigação das solicitações de cisalhamento em edifícios de alvenaria estrutural submetidos a ações horizontais. Dissertação (Mestrado) - Escola de Engenharia de São Carlos Universidade de São Paulo.

[09] NASCIMENTO NETO, J.A.; CORRÊA, M.R.S. (2002). Análise tridimensional de edifícios em alvenaria estrutural submetidos à ação do vento. Cadernos de Engenharia de São Carlos, n.19, p. 81-100, São Carlos, 2002.

[10] NUNES, V.Q.G. (2011). Análise estrutural de edifícios de paredes de concreto armado. Dissertação de mestrado pela Escola de Engenharia de São Carlos, da Universidade de São Paulo, São Carlos, 2011.

[11] YAGUI, T. (1971). Estruturas constituídas de paredes delgadas com diafragmas transversais. Tese (Doutorado) - Escola de Engenharia de São Carlos, Universidade de São Paulo, 1971.

[12] COMPUTERS \& STRUCTURES INC. (2011). CSI Analysis reference manual for SAP2000. Berkeley, California, USA, 2011. 